\title{
18. YÜZYILA AİT BİR TÜRKÇE SARF KİTABI: HĀZ̄Ā KİTĀB-I SARF-I TÜRKî
}

\section{AN 18TH CENTURY TURKISH GRAMMAR BOOK: HĀZ̄Ā KİTĀB-I SARF-I TÜRK $\hat{I}$}

\author{
Sevda KAMAN* \\ Elif Gizem KARAOĞLU**
}

\begin{abstract}
$\ddot{O} z$
Berlin Devlet Kütüphanesi Doğu El Yazmaları Koleksiyonu'nda Ms. Diez A quart. 95 numarasıyla kayıtlı Hāzā Kitāb-ı Sarf-ı Türkî̀ (H. 1201/M. 1786) adlı eser, 1b-10a varakları arasında yer alan küçük bir Türkçe sarf (şekil bilgisi) kitabıdır. Eserin 1b-7b varakları arasında eşya-alet, at biniş-koşum takımı, içecek, silah, giysi, ayakkabı, kumaş, hayvan, yiyecek, meyve, organ, mesken, bitkibaharat, boya, kimyevi madde isimleri sıralanmış; daha sonra bu isimlerden birçoğunun iyelik çekimleri (3. teklik kişi iyelik çekimi hariç) verilmiştir. İsimlerin iyelik çekiminden sonra $7 b$-8a varakları arasında basit ve birleşik zamanl fiil çekimlerine örnekler verilmiştir. Eserin 8b-10a arasındaki varaklarında ise 18. yüzyıl İstanbul'unun meslek isimleri (193 adet) "Bâb u fî̀ Beyân-ı Esnâfları" alt başlı̆̆ında listelenmiştir. Osmanlı Türkçesi gramer kitaplarından Müyessiretü'l-Ulûm (M. 1530)'dan sonra en eski tarihli gramer kitabı olan Hāzāa Kitāb-ı Sarf-ı Türkî, 18. yüzyıl Türkçesinin söz varlığııı ve şekil özelliklerini içermesi açısından önemli olduğu kadar 18. yüzyıl İstanbul'unun sosyal ve meslek hayatına, dönemin günlük hayat kültürüne ışık tuttŭ̆u için de dikkate değerdir. Bu makalede amaç eseri Türkoloji dünyasına tanıtmak ve 18. yüzyıl Türkçesi üzerine yapılan çalışmalara katkıda bulunmaktır.
\end{abstract}

\section{Anahtar Kelimeler}

Osmanlı Türkçesi, sarf (şekil bilgisi), 18. Yüzyıl, İstanbul meslek isimleri

\section{Abstract}

The Hāzā Kitāb-ı Sarf-ı Türk̂̀ (h.e. 1201/c.e. 1786), which is registered with the number Ms. Diez A quart. 95 at the Berlin State Library Eastern Manuscripts Collection is a small Turkish grammar (morphology) book located between the 1b-10a pages. Between the $1 b$-7b pages of the work, the names of goods-tools, horse riding-harnesses, beverages, weapons, clothes, shoes, fabric, animals, food, fruits, organs, dwellings, plants-spices, paint, chemical substances are listed; afterwards, possessive suffixes of many of these names were given (except for the $3 \mathrm{rd}$ person singular possessive suffixes). Between the pages $7 b-8 a$, simple and compound tense verb inflection examples are given. In the pages between $8 b-$

\footnotetext{
Dr. Öğr. Üyesi, Bartın Üniversitesi Edebiyat Fakültesi Türk Dili ve Edebiyatı Bölümü, skaman@bartin.edu.tr, ORCID: htttps://orcid.org/0000-0001-8167-8961 Bartın TÜRKIYE

** Öğr., Gör., Sosyal Bilimler Meslek Yüksekokulu, (Doktora Öğrencisi, Bartın Üniversitesi Lisansüstü Ĕ̆itim Enstitüsü, Türk Dili ve Edebiyatı Anabilim Dalı), elifkaraoglu92@gmail.com, ORCID: htttps://orcid.org/0000-0001-9144-4229 Bartın TÜRKIYYE
} 
$10 a$ of the work, the occupational titles of 18th-century Istanbul (193 titles) are listed under the subheading "Bâb u fî Beyân-ı Esnâfları". Hāzzā Kitäb-ı Sarf-ı Türkî̀, which is the oldest grammar book after Müyessiretü'l-Ulûm (C.E. 1530), one of the Ottoman grammar books, is noteworthy as it includes the lexical and morphological features of 18th-century Turkish as well as it sheds light on the social and professional life of 18th century Istanbul and the daily life culture of the period. The purpose of this article is to introduce the work to the world of Turcology and to contribute to the studies on the 18thcentury Turkish.

\section{Keywords}

Ottoman Turkish, grammar (morphology), 18th century, occupational titles in Istanbul 


\section{GİRIŞ}

Arapça kökenli sarf sözcüğünün asıl anlamı "harcama, tüketme, kullanma” iken terim anlamı "dil bilgisi, yapı bilgisi"dir (TDK, Türkçe Sözlük, https://sozluk.gov.tr/). Osmanlı Türkçesinde "dil bilgisi" için daha çok sarf ve (ü) nahiv ifadesi tercih edilmiştir. Sarf kitaplarında amaç dilin doğru söylenip yazılıp okunmasını sağlamak ve kurallarını ortaya koymaktır.

Türkçenin grameriyle ilgili çalışmaların tarihî süreci XI. yüzyılın ikinci yarısında Kaşgarlı Mahmut'un kayıp eseri Kitâbu Cevâhir Nahv fi-Lûgat-it-Türk ile başlar. Korkmaz, Türkiye Türkçesi ile ilgili gramer çalışmalarını üç başlık altında toplamıştır: Osmanlı dönemi gramerleri, Tanzimat dönemi gramerleri, Cumhuriyet dönemi gramerleri (2019, s. 87). Türkiye Türkçesi grameri ile ilgili ilk çalışma Bergamalı Kadri'nin 1530'da Kanuni Sultan Süleyman'ın sadrazamı İbrahim Paşa'ya sunduğu Müyessiretü'l-Ulûm adlı eseridir (Karabacak, 1999, s. 629). Müyessiretü'lUlûm'dan önce Divriğili Fahreddin Efendi tarafından XIII-XIV. yüzyıllarda Kasîdetü fi-Kavâid-i Lisâni't-Türk adlı manzum bir gramerin yazıldığı fakat bu gramerin de kayıp eserlerimiz arasında bulunduğunu belirtmekte fayda vardır (Korkmaz, 2019, s. 87). Bunların dışında Gülşenî şeyhlerinden Mehmet Muhiddin'in 1579'da yazdığı Bâleybelen adlı eseri Türkçe, Farsça, Arapça esas alınarak ortaya konulan yapma bir dilin grameridir. Koç, bu yapma dilin bütün gramerinin Türkçedeki karşılıklarını vermek için Mehmet Muhiddin'in çalışmasının mukayeseli bir gramer yapısında gerçekleştiğini ve böylelikle Türkçenin ilk yapı bilgisi ve ilk zamirler kitabının bu şekilde ortaya çıktığını ifade etmiştir (Koç, 2008, s. 272). Bu eserin gramer çalışmaları arasında sayılmamasının sebebi Şeyh Mehmet Muhiddin'in Türkçe, Farsça ve gerektiğinde Arapçadan yaptığı özel katışmalarla ortaya çıkardığı yapay dilin gramerini işlemiş olması ve müstakil bir Türkçe gramer çalışması olmamasıdır.

Türk gramerciliği Tanzimat'a kadar verimsiz bir dönem geçirmiştir çünkü Türkçe bu dönemde yoğun bir şekilde Arapça ve Farsçanın tesiri altında kalmıştır. Dolayısıyla bu dönemde hazırlanan çalışmalar söz konusu dillerin yapı ve şekillerini ortaya koymuştur. Korkmaz bu dönemi şöyle değerlendirmiştir:

“Osmanlı Türkçesi içindeki Türkçe nasıl horlanmış ve geri plana itilmiş ise, Türk dilinin grameri de ayn ihmal ve küçümsemeye uğramıştır. Osmanlı Devletinde medrese dilinin Arapça olması, bol bol Arapça gramerlerin yazılmasına yol açmıştır. XVI-XIX. yüzyıllar arasında Türkçenin yapısı ile ilgili olarak, yalnız Bergamalı Kadri'nin, Müyessiretü'lûlum'u gibi tek bir eserin elde bulunması, genellikle böyle bir ihmalin sonucudur." (2002, s.

42)

Gramer çalışmalarının ivme kazandığı Tanzimat döneminin başlıca çalışmaları şunlardır: Mehmed Fuad ve Ahmed Cevdet Paşa Medhal-i Kavâid (1851), Kavâid-i Osmâniye (1865), Kavâid-i Türkiye (1875), Tertîb-i Cedîd Kavâid-i Osmâniye (1875); Süleyman Paşa İlm-i Sarf- Türkî (1874); Ali Nazima Lisân-ı Osmânı̂ (1880); Selim Sabit Sarf-ı ve Nahv-i Osmânı̂ (1881); M Kütahyalı Abdurrahman Fevzi Efendi Mikyâsu'l-Lisân Kıstâsu'l-Beyân ${ }^{1}$ (1881), Mehmed Rufat Külliyât-ı Kavâid-i Osmâniye (1885); Abdullah Ramiz Paşa Emsile-i Türkî (1886); Şemseddin Sami Nev Usûl Sarf-ı Türkî (1892); Necib Asım: Osmanlı Sarfı (1894); Mehmed Rıfat Hâce-i Lisân-ı Osmân̂̀ (18941895); Şeyh Efendi Mufassal Yeni Sarf-ı Osmânî (1901). Tanzimat sonrasından 1908 Meşrutiyetine

\footnotetext{
${ }^{1}$ Kütahyalı Abdurralıman Fevzi Efendi Mikyâsu'l-Lisân Kıstâsu'l-Beyân adlı eserini 1846'da yazmaya başlamış, dört yıl sonra bitirmiştir. Eserin yayımlanma tarihi ise 1881'dir (Karabacak, 2018, s. 1).
} 
kadar çalışmalar hızla devam etmiştir. Bu dönemde hazırlanan gramerlerde yer yer konuların ele alınışı, sınıflandırılması, adlandırılması gibi bazı yenileşmeler olmuşsa da Türk gramerinin temel konuları ve terim sistemi açısından genellikle eski gelenek ve anlayışın ağırlıkta olduğu söylenebilir. 1908' den 1928 yılına kadar gramer anlayışında ve yazılan gramerlerde bir değişim olduğu göze çarpmaktadır. Bu dönemde tarihî Türk gramerciliğinde Arapça ve Farsça etkisindeki gramer anlayışının yerini Batı gramerciliğinin aldığı görülmüştür. Dönemin öne çıkan çalışmaları şöyledir: Hüseyin Cahid Yalçın: Türkçe Sarf ve Nahiv (1908); Ahmet Cevat Emre: Lisân-ı Osmân̂̂ (1912) (Korkmaz, 2019, s. 91-92). Türk Dil Kurumu Gramer Bilim ve Uygulama Kolunun “Türkiye Türkçesi ve Tarihî Devirler Yazı Dilleri Gramerleri Projesi” kapsamında 1928 yılından önce yazılan gramer kitapları yeni harflere aktarılmış; ayrıca söz konusu kitaplar yüksek lisans, doktora tezi, doçentlik çalışmaları olarak da hazırlanmıştır. Görüldügüü üzere Türkçenin gramerine yönelik çalışmalar "sarf ve nahiv" olarak yani "yapı bilgisi ve söz dizimi" çerçevesinde ele alınmıştır. Sadece "sarf" başlığı altında hazırlanan eserler şunlardır:

Süleyman Paşa: İlm-i Sarf-ı Türkî (1874), Selim Sabit: Sarf-ı Osmanî (1881), Mihrî:

Mutavvel Sarf-ı Osmânî (1890), Şemseddin Sami: Nev Usûl Sarf-ı Türkî (1892), Necip

Asım: Yeni Usûl Osmanlı Sarfı (1896), Şeyh Vasfì: Mufassal Yeni Sarf-ı Osmân̂̂ (1901),

Komisyon: Mufassal Yeni Sarf-ı Osmânî (1908), Ahmed Rasim: Tecrübeli Sarf (1922)

(Korkmaz, 1992, s. VII-VIII)

Bu bilgiler ışığında bu makalede ele alınan Hāzāa Kitāb-ı Sarf-ı Türkî (1786)'nin Osmanlı Türkçesi gramer kitaplarından Müyessiretü'l-Ulûm (1530)'dan sonra en eski tarihli gramer kitabı olduğunu söylemek mümkündür. Bu durum da eserin önemini gözler önüne sermektedir.

18. yüzyıla ait bir Türkçe sarf kitabı olan Hāzē Kitāb-ı Sarf-ı Türkî'nin ele alındığı bu çalışma giriş, inceleme, metin, sözlük bölümlerinden oluşmaktadır. Çalışmanın giriş bölümünde tarihî gramer çalışmaları hakkında bilgiler aktarılmıştır. İnceleme bölümünde eserin kimliği, müellifi, yazmanın tavsifi, eserin içeriği, önemi ve dil özellikleri hakkında bilgiler verilmiştir. Yazarın hem söyleyiş̧e hem de eski yazı (kalıplaşmış imla) geleneğine uygun yazdığı görüldüğü için metin transkripsiyon alfabesine aktarılırken esere sadık kalınmıştır. Eserin yazımında eksik bırakıldığı düşünülen ekler [ ] işaretleri içinde tamamlanmıştır ancak metne çok fazla müdahale etmemek adına eksik sözcük çekimleri dipnotlarda belirtilmiştir. Okunuşundan ve anlamindan emin olunmayan sözcük ve ibarelerin sonuna (?) konulmuştur. Bunun dışında metne sadık kalınmış, herhangi bir noktalama işareti eklenmemiştir. Çalışmadaki 18. yüzyıldaki esnaf ve zanaatkâr isimlerinin karşıllklarının verilmesinde tarihî anlamları esas alınmıştır. Bu sebeple meslek isimlerinin okunuşunda ve sözlük hazırlanırken Evliya Çelebi'nin Seyahatnâme (2003), Reşat Ekrem Koçu'nun Tarihte Istanbul Esnafi (2016), Carbognano'nun 18. Yüzyılın Sonunda Istanbul (1993), Zafer Toprak'ın Zanaattan Küçük ve Orta Büyüklükteki Issletmelere Lonca'dan Kobi'ye Esnaf ve Sanatkârın Dünü (2004), Sadık Müfit Bilge'nin Osmanlı İstanbul'unda Esnaf ve Ticaret (2018) adlı eserlerinden, Miyase Koyuncu'nun 18. Yüzyılın İkinci Yarısında Osmanlı Esnafı (Istanbul ve Bursa Örnekleri) (2004) adlı doktora tezinden; Tarih Terimleri Sözlüğ̈̈ (1974), Osmanl Tarih Deyimleri ve Terimleri Sözlüğ̈̈ (1983), Thesaurus Linguarum Orientalium Turcicae-Arabicae-Persicae: Lexicon (1680), A Turkish and English Lexicon (1987), Kāmûs-ı Türkî (1901), Lehçe-i Osmânî (1890), Misalli Büyük Türkçe Sözlük (2005), Tarama Sözlü̆̆̈̈ ve Derleme Sözlüğ̈̈, Türkçe Sözlük adlı sözlüklerden yararlanılmıştır. 


\section{Eserin İncelenmesi:}

\subsection{Eserin kimliği, müellifi ve yazmanın tavsifi:}

Hāżā Kitāb-ı Sarf-ı Türkî, 1b-10a varakları arasında yer alan küçük bir şekil bilgisi kitabıdır. Berlin Devlet Kütüphanesi Doğu El Yazmaları Koleksiyonu'nda (Staatsbibliothek zu Berlin Preußisscher Kulturbesitz/Orientalische Handschriften) Ms. Diez A quart. 95 numarasiyla (http://resolver.staatsbibliothek-berlin.de) kayıtlıdır. 7b'deki ketebe kaydında H. 1201 (M. 1786) tarihi ve "seveddehü İbrahim Efendi" ifadesi bulunmaktadır:

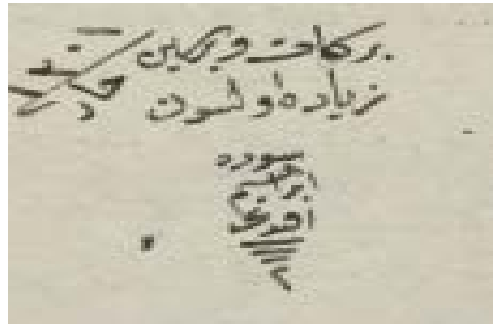

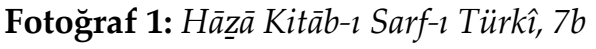

"Seveddehü" ifadesi ile eseri yazanın (karalayanın) İbrahim Efendi olduğu ifade edilmiştir. İbrahim Efendi eserin yazarı olabileceği gibi müstensihi de olabilir. Dolayısıyla esere not düşülen tarih H. 1201 (M. 1786) telif tarihi olabileceği gibi istinsah tarihi de olabilir ancak genellikle eserin bir müsveddeden temize çekildiğine dair ifadeler telif kaydı olarak düşünülmektedir (Çetin, 1971, s. 62). İSAM Tahkikli Neşir Esasları'na göre "Elimizde sadece müsvedde nüsha varsa, onu "müellif nüshası" olarak değerlendirmek gerekmektedir." http://www.isam.org.tr/documents/_dosyalar/_pdfler/Nesir_Kilavuzu_13Mart.pdf). Eserde İbrahim Efendi ile ilgili başka bir bilgi yoktur. Eserin yazılış amacını belirten veya yazarı hakkında bilgiler içeren bir ön söz (mukaddime) yer almamaktadır. Osmanlı arşivi ve literatürü tarandığında İbrahim Efendi ile ilgili bir bilgiye ulaşılamamıştır. Eserde İstanbul meslek isimleri (193 adet) ve "Kilitciler Ḧânı" ifadesi yazarın bir İstanbul sakini olduğu ihtimalini akla getirmektedir. Ayrıca kütüphane kataloğunda yazmanın bulunduğu yer İstanbul olarak gösterilmiştir. Yazmayı bulup kütüphaneye bağışlayan Heinrich Friedrich von Diez (17511817)'dir. Schmiede, Heinrich Friedrich von Diez'in Prusya'nın elçisi iken İstanbul'da kaldığ yıllarda (1784-90) İstanbul'dan Türkçe, Arapça, Farsça birçok yazmayı topladığını; ölümünden sonra 17.000 cilt basma kitap ve 835 yazmayı Berlin Kraliyet Kütüphanesine bağışladığını aktarmıştır (t.y., s. 7, 8). Bu makalede incelenen Hāzā Kitāb-ı Sarf-ı Türkî̀nin Berlin Devlet Kütüphanesi tarafından açık erişime sunulma tarihi 6 Eylül 2019'dur. Bu durum Diez' in topladığ yazmalar arasında henüz kaydedilmediği için bilim dünyasına sunulmamış, incelenmemiş daha birçok yazmanın varlığına işaret etmektedir.

Eserin 1b-7a arasındaki varaklarında satır sayısı on üç, sonrakilerde ise düzensizdir. Yazı türü divânîdir. Siyah mürekkeple yazılmıştır. Nüsha, kahverengi deri ciltle kaplıdır. Sayfa ölçüsü 21,5 x 15,5 cm, cilt ölçüsü 21,9 x 15,7 x 0,4cm'dir. 1b'de Hāzā Kitāb-ı Sarf-ı Türkî başlığı yer almaktadır:

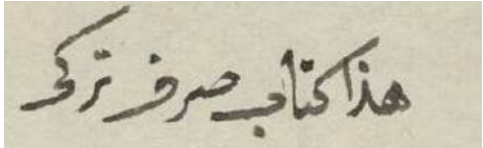

Fotoğraf 2: Hāza $\bar{a}$ Kitāab-ı Sarf-ı Türkî, $1 b$ 
8b/01'deki "Bâb u fî Beyân-ı Esnâfları" başlı̆̆ı altında meslek isimleri (8b-10a arasında) sıralanmıştır. Diez, eserde bahsi geçen İstanbul meslek isimlerini (193 adet) Almancaya çevirerek yazmanın sonundaki varaklara kendi el yazısıyla listelemiştir:

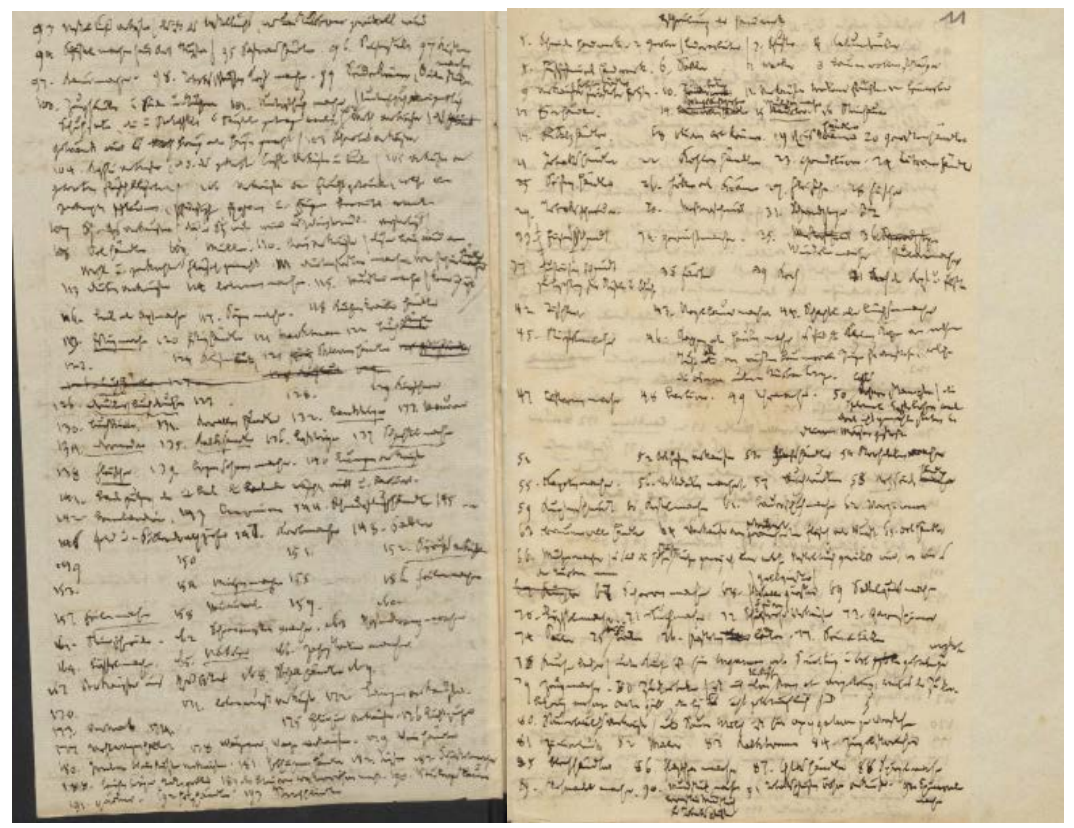

Fotoğraf 3: Hāzāa Kitāb-ı Sarf-ı Türkî, 12a-12b

\subsection{Eserin içeriği ve önemi:}

18. yüzyılda yazılmış bir şekil bilgisi kitabı olan Hāzā Kitāb-ı Sarf-ı Türkî, Türkçenin yapısı ile ilgili olarak 16-19. yüzyıllar arasında yazılmış günümüze ulaşan tek eserin Müyessiretǘl(M. 1530) olmadığını göstermektedir. Hāzz̄ā Kitāb-ı Sarf-ı Türkî, yazılış tarihi bakımından önemli olduğu kadar yazım özellikleri açısından da dikkate değerdir. Hāzzā Kitāb-ı Sarf-ı Türkì'de kimi sözcüklerin okutucu ünlülerle veya harekeli; kimi sözcüklerin söyleyiş (telaffuz) esas alınarak yazılması Osmanlı Türkçesinde eklerin ses düzeni ile ilgili çalışmalara katkı sağlayacak bir eser olduğuna işaret etmektedir.Eserin $1 \mathrm{~b}-7 \mathrm{~b}$ varakları arasında eşya-alet (şam'dān, miḳ̂ās, mūm, çubuk, ibrīk, māşa, șofra, kaş̧ık, bıçak, minder, yașdık, yorğan, çārşaf, seccāde, kilim, hall, kalem, kalemtıraş, kāğıt, peşkir, yağllk), at biniş-koşum takımı (rāht, bāht), içecek (kahve, şerbet, süd, su) silah (kıllıc, tüfenk), giysi (kaput, biniş, kürk, kaftān, entāri, yelek, gömlek, țon, çakş̧ı, yemānī, şāl, kuş̧ak, șarık, duvak), ayakkab1 (mest, pabuc, çizme), kumaş (çuka, alaca, abā, kebe), hayvan (at, kedi, horuz, tavuk, kaz, ördek, koyun, kuzu, keçi, manda, katır, eşek, öküz, kııșrag̀/kısrak, deve, arslan, kaplan, tilki, köpek, ḳurd, ayu, țavşan, keklik, bülbül, serçe, ḳanarya, țūțī, ḳumrl, şāhin) yiyecek (şeker, tuz, ekmek, kaymak, yag̀, bal, ta am) meyve (incīr, üzüm, ceviz, alma, amrūd, nār, kiras, ayva, erik, kaysı, şeftāli) organ (el, ayak, göz, kulak,

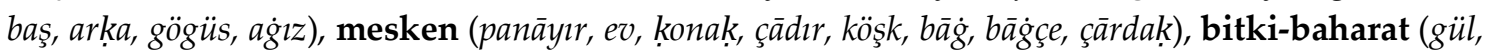
sünbül, lāle, karanfil, zencebīl, yenibahār, kimyūn, biber, dārçı̄n, sināmekī, dār-l fülfül, besbāse, kebābiyye, kardaş kanı, 'ūdüll-kahr, kakūle, loțūr, māżl, Hindüstān cevizi, za ferān, günlik, kara zirre, kașnl, yüzerlik/yüzlük(?), peyg்amber aǵacl, tütün), boya isimleri (çivit, kırmız, rastık) ve kimyevi maddeler (kalem-i cengārr, kükürt, nışādır, göz țaşı, șaçıkıbrız, 'anber) sıralanmıştır. Bu isimlerden "miḳrāș, māşa, şerbet, kumrl, süd, sināmekī, dār-ı fülfül, besbāse, kebābiyye, kardaş kanı, 'üdü'l-kahr, kalem-i cengār, çivit, kakūule, kükürt, kıımız, loțūr, mā̇̀ı, rastık, nışādır, Hindüstān cevizi, göz țaşı, za ferān, kara zirre, kașnı, șaçıkıbrız, peyǵamber ağacı, kilim, hall, duvak, kalemtıraş, kāğıt" dışındakilerin iyelik çekimi (3. teklik kişi iyelik çekimi hariç) yapılmıştır. Yazar hayvan adlarından sonra 2a/01-03'te "geldi gitdi aldı virdi kodı kordı buldı durdı șordı döndi çıḳdı çevirdi" gibi günlük hayatta sıklıkla kullanıldığını 
düşündüğü fiillerin görülen geçmiş zaman çekimlerini sıralamıştır. 5a/04-13'te bu fiillerin (korhariç) kişilere göre çekimi şu sıraya göre yapılmıştır:

\begin{tabular}{|c|c|}
\hline $5 a / 04$ & geldi geldim geldin geldik geldiniz geldiler idi \\
\hline $5 a / 05$ & gitdi gitdim gitdin gitdik gitdiniz gitdilerdi \\
\hline $5 a / 06$ & aldı aldım aldu \\
\hline $5 a / 07$ & 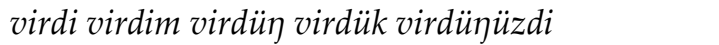 \\
\hline $5 a / 08$ & 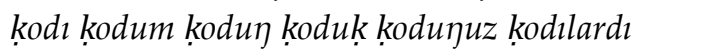 \\
\hline $5 a / 09$ & buldı buldum buldı bulduk bulduๆuz buldılardı \\
\hline $5 a / 10$ & durdı durdum durduך durduk durdunuz \\
\hline $5 a / 11$ & 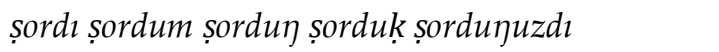 \\
\hline $5 a / 12$ & 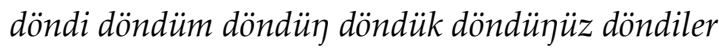 \\
\hline $5 a / 13$ & çevirdi çevirdüm çevirdǖ çevirdik çevirdīüz \\
\hline
\end{tabular}

Eserin $7 \mathrm{~b}-8 \mathrm{a}$ varakları arasında gel-, ye-, iç-, sev-, oku- fiillerinin basit ve birleşik zamanlı çekimlerine örnekler verilmiştir:
7b/01 geldim idi geldin idi geldik idi geldinizdi
7b/02 geldiler idi gelseydim gelseydi
7b/03 gelseydik gelseydiniz gelselerdi
7b/04 yedim idi yemedi $\quad$ idi yemedi idi yemedilerdi
7b/05 yedim içdim yedin içdin yedi içdi
7b/06 yedik içdik yediniz içdiniz yediler içdiler
8a/01 sevdim idi sevecek idim sevsem idi sever idim
8a/02 severim seviserim sevsem gerek sevecegim
8a/03 sevmem seumezim sevmedim sermezdim sermeyecekdim
8a/04 sevmedim idi sevmezdim sevmem gerek idi
8a/05 sevseydim serseydin sevseydik sevseydiniz sevselerdi
8a/06 sevmedim idi sevmediๆ idi sevmedik idi sevmedilerdi
8a/07 sevmez idim seumez idin sevmez idik seumezler idi
8a/08 sevmesem gerek idi sevmesen gerek idi sevmesek gerek idi
8a/09 sevmeseler gerek idi sevecek idim sevecek idin sevecek idik

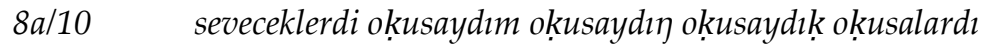

Eserin 8b-10a arasındaki varaklarında yer alan "Bâb u fî Beyân-1 Esnâfları" alt başlığında 18. yüzyıl İstanbul'unun 193 mesleği (esnaf ve zanaatkâr isimleri) listelenmiştir. Bu bölümde meslek isimleri dışında yer adları (bedesden 10a/01, așbahā pazarı (?) 10a/09, Kilitciler Ḥānı 9b/05) da dikkati çekmektedir. Aynı anlama gelen meslek isimleri ise "beyzciler-yumurțacılar, duhān kııyıcılar-tütün kııyıcılar, ipekciler-kazzāzlar" şeklindedir. Yazar sıraladığı meslek sayılarını her satırın sonunda, satırdaki sayıların toplamını her sayfanın altında, toplam sayıyı da eserin son sayfasında şu şekilde göstermiştir:
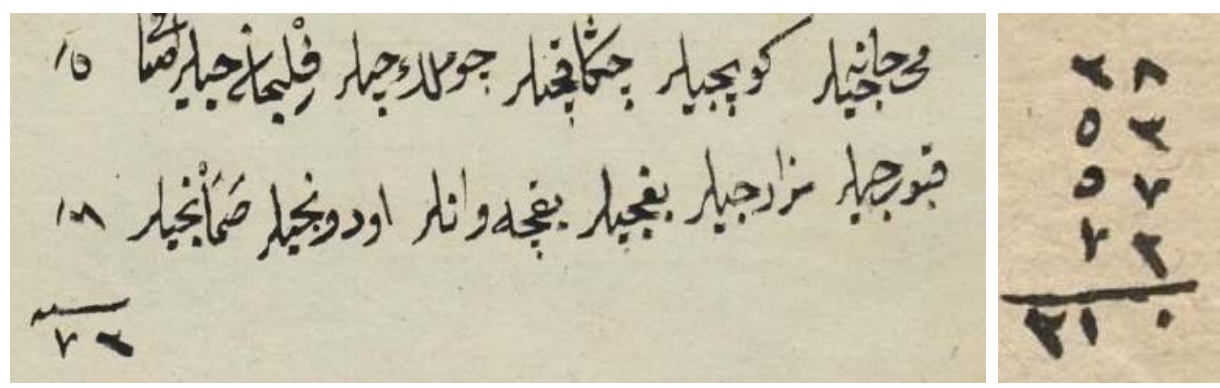

Fotoğraf 4: Hāzā Kitāb-ı Sarf-ı Türkî, 10a, 13a 
Aşağıdaki tabloda belirtildiği üzere bazı meslekler iki kez yazılmıştır:

Tablo 1: Eserde siralanan esnaf ve zanaatkâr isimleri

\begin{tabular}{|c|c|c|c|}
\hline 1. abācılar & 2. $\quad$ akcılar & 3. arabacılar & 4. arpacilar \\
\hline 5. aşcılar & 6. așdarcılar & 7. aynacilar & 8. bacacilar \\
\hline 9. bāğcilar & 10. bāg̣çevānlar & 11. bal mūmcılar & 12. balıkecilar \\
\hline 13. bārūtcılar & 14. bakırcılar & 15. bakkkallar & 16. bașmacılar \\
\hline 17. berberler & 18. beyzciler & 19. bezzāzlar & 20. boyacilar (2) \\
\hline 21. bozacilar & 22. börekciler & 23. cāmcilar & 24. cemmāzlar(?) \\
\hline 25. cigerciler (2) & 26. çaḳmaḳcılar & 27. çanaḳcılar & 28. çarḳcilar (2) \\
\hline 29. çırbıcılar & 30. çorabcilar & 31. çömlekciler (2) & 32. çörekciler \\
\hline 33. çubukcular & 34. çukacilar & 35. damḳacılar & 36. debbāg \\
\hline 37. degirmenciler & 38. desdereciler & 39. divārcılar & 40. divīdciler \\
\hline 41. dog̀ramacilar & 42. dörpüciler & 43. dugìūcılar & 44. duhāncılar \\
\hline 45. duhāan ḳıyıcılar & 46. dügmeciler & 47. dülgerler & 48. egeciler \\
\hline 49. ekmekciler & 50. enserciler & 51. esīrciler & 52. eskiciler \\
\hline 53. fenerciler & 54. fesciler & 55. filcāncilar (2) & 56. gözlemeciler \\
\hline 57. haffāflar & 58. hakkāklar & 59. halıcilar & 60. hallāclar \\
\hline 61. hammāllar & 62. ḥașırcilar & 63. helvācılar & 64. horașāncilar \\
\hline 65. hoşāābcılar & 66. 1rḳatlar & 67. igneciler (2) & 68. imāmeciler \\
\hline 69. ipekciler & 70. iplikciler & 71. iskemleciler & 72. kabuḳcılar \\
\hline 73. kadāyıfcılar & 74. kafesciler & 75. kāgitṭcılar & 76. kahveciler \\
\hline 77. kalaycilar & 78. kalibcilar & 79. kalyoncılar & 80. kanțarcılar \\
\hline 81. karulacılar (?) & 82. k kașșāblar (3) & 83. ḳașșarlar & 84. kaşıkcılar \\
\hline 85. kavurci[lar] & 86. kavuḳcılar & 87. kayılkcılar & 88. ḳazāncılar \\
\hline 89. kazzāzlar & 90. kebābcılar & 91. keçeciler & 92. kelesteciler \\
\hline 93. kerpicciler & 94. keserciler & 95. keşkekciler & 96. kettāncılar \\
\hline 97. ḳılabdāncılar (2) & 98. kilicc1 & 99. kıncilar & 100. kıymacılar \\
\hline 101. kirecciler & 102. kiremitciler & 103. kirişciler & 104. kolancılar \\
\hline 105. kolțuḳcılar & 106. ḳopçacılar & 107. kömürciler & 108. kubūrcılar \\
\hline 109. kumbaracilar & 110. kundaḳcılar & 111. kuru yemişciler & 112. kuşaḳcılar \\
\hline 113. kutucucilar (2) & 114. küpciler & 115. kürkciler & 116. laġımcılar \\
\hline 117. leblebīciler & 118. limoncilar & 119. lüleciler & 120. makascılar \\
\hline 121. meyḥāneciler & 122. mezārcılar & 123. misvākcılar & 124. muhallebciler \\
\hline 125. mücellidler & 126. mühreciler & 127. mürekkebciler & 128. mūmcılar \\
\hline 129. mūțaflar & 130. nalbant & 131. nalburlar & 132. nalçacılar \\
\hline 133. naḳkāşlar & 134. oduncilar & 135. oturakcilar & 136. örekeciler \\
\hline 137. örekciler (?) & 138. örücüler & 139. pașdırmacılar & 140. pabuccılar \\
\hline 141. pambukccilar & 142. parmaḳcilar & 143. pașdırmacılar & 144. pekmezciler (2) \\
\hline 145. bıçak. [çı]lar & 146. pirincciler & 147. sā'atciler & 148. șābūncilar (2) \\
\hline 149. șafrancilar & 150. șaḥhāflar & 151. șamancılar & 152. sandiḳcılar \\
\hline 153. șarāclar (2) & 154. sebzevātcilar & 155. sepetciler & 156. șirıkcilar \\
\hline 157. simitciler & 158. sirkeciler & 159. şālcılar & 160. şekerciler \\
\hline 161. şerbetciler & 162. şīşeciler & 163. tācirler & 164. taḩmīsciler \\
\hline 165. tekneciler & 166. tekyeciler & 167. tellāklar & 168. temürciler \\
\hline 169. tenekeciler & 170. terlikciler & 171. terzì & 172. tesbihciler \\
\hline 173. țarakçılar & 174. țaşcilar & 175. țavuḳcılar & 176. topcilar \\
\hline
\end{tabular}




\begin{tabular}{|c|c|c|c|}
\hline 177. tökmeciler & 178. țurşucular & 179. tuzcilar & 180. tülbentciler \\
\hline 181. tütün kııııılar & 182. unḳapancılar & 183. usturacilar & 184. vezneciler \\
\hline 185. yaǵcılar & 186. yaṣdıḳcılar & 187. yaġlıkccllar & 188. yemenīci \\
\hline 189. yoġurtcılar & 190. yorgancılar & 191. yumurțacılar & 192. zeytūncılar \\
\hline 193. zeytūnyağcılar & & & \\
\hline
\end{tabular}

\subsection{Eserin dil özellikleri:}

18. yüzyıl, Osmanlı Türkçesinin Timurtaş'ın (1997, s. 2) ve Duman'ın (1998, s. 1) "Klasik Osmanlıca", Deny'nin (1941, s. II) "Eski Osmanlıca", Erdal'ın (1994, s. 69) "Orta Osmanlıca", Develi'nin (1998, s. 27) "Yeni Türkiye Türkçesi” olarak nitelendirdiği döneme dâhil edilmektedir. Develi, 18. yüzyılı bugünkü standart yazı dilimize temel teşkil eden "Yeni Türkiye Türkçesi"nin ses düzeninin esaslı olarak oluştuğu bir dönem olarak görmektedir ve 18. yüzyılı önceki dönemlerden ayıran fonolojik özellikleri dudak uyumları sürecinin tamamlanmış olması, Eski Türkiye Türkçesindeki kelime başı /i/ fonemlerinin /è/'ye dönüşmesi, bazı eklerde görülen, ancak henüz tamamlanmamış olan /n/ > /n/ gelişmesi şeklinde sıralamıştır (1998, s. 31-32). Çalışmanın bu bölümünde eserin dil özellikleri "yazım özellikleri, ses ve şekil bilgisi özellikleri” başlıkları altında incelenmiş ve eser yazıldığı döneme göre değerlendirilmiştir.

\subsubsection{Yazım özellikleri:}

Eser dönemin söyleyiş özelliklerini yansıtmaktadır ancak gerek sözcük yazımında unutulan sesler, ekler, sözcükler gerekse de sözcüklerin ikili yazılımı, iyelik çekim sıralamasındaki ve fiil çekimlerindeki düzensizlik eserin özensiz yazıldığını göstermektedir. Eserde bazı sözcük ya da eklerdeki ünlüler harekeli yazılmıştır; bunlardan birkaçı şöyledir:

dörpüciler 10/07, mühreciler10/03, çādır 2a/07, amrūd 2a/04, süd 2a/03, ķoyun 4a/08, ördek 1b/08

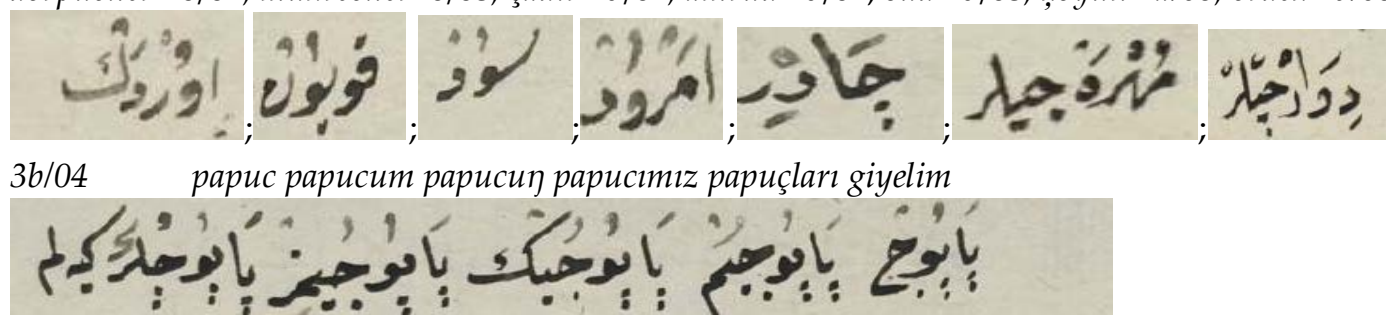

Eserde sözcük ya da eklerdeki ünlüler bazen de okutucu harflerle yazılmıştır:

4b/01 öküzüm öküzi门 5a/10 durdı durdum durduๆ durdukdurdunuz

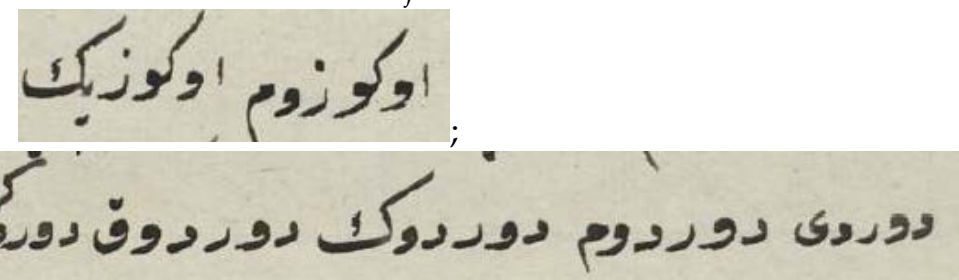

Bu durum Arap harflerinin sözcük ve eklerin okunmasındaki yetersizliklerini bir nebze olsun azaltmaktadır ve 18. yüzyıl Türkçesi hakkında sözcüklerin söylenişi ve eklerin ses düzeni hakkında ipuçları vermektedir. Eserde sözcüklerin yazımında ikilikler tespit edilmiştir:4b/02 kııșrağ/ kııșrakları; erik 5b/12/erik 2a/05; tavuḳ/țavukları 4a/05; ḳurd/kurtları 4b/08, 4a/12; katır 1b/09/kațır 4a/12.

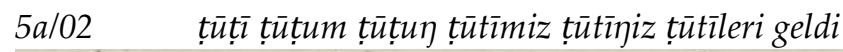

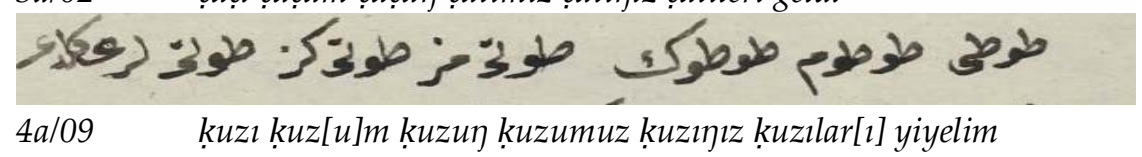




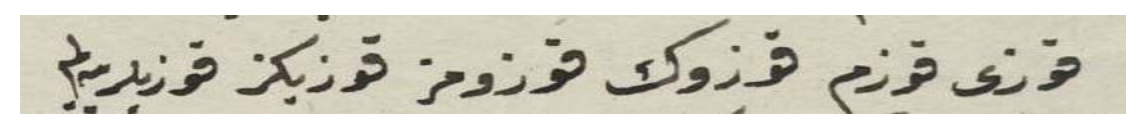

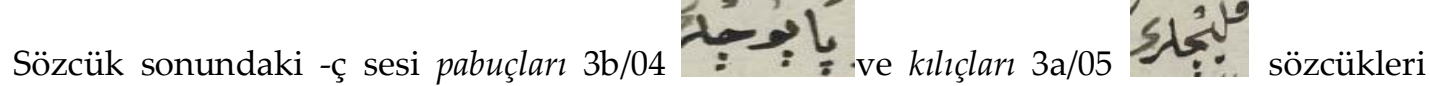
dışında cim (ج) ile yazılmıştır. Eserin yazım özellikleri yazarın yer yer söyleyişe yer yer de eski imlaya uygun yazdığını bu bakımdan metinde tutarlılık olmadığını göstermektedir.

\subsubsection{Ses bilgisi özellikleri:}

Damak Uyumu: 16-18. yüzyıllardaki Osmanlı Türkçesi metinlerinde olduğu gibi eserdeki eklerde de damak uyumu tamdır.

Dudak Uyumu: Kartallığlu'na göre Osmanlı Türkçesindeki dudak uyumu 16. yüzyılda "uyumsuzluk-düzensizlik", 17. yüzyılda "düzensizlik-geçiş" ve 18. yüzyılda "geçiş-uyum" safhalarındadır (2011, s. 70). H. 1201/M.1786 tarihli Hāzzā Kitāb-ı Sarf-ı Türkî'nin dudak uyumuna göre "geçiş-uyum" niteliğini taşıdığı görülmektedir. Arap harfli metinlerde dudak uyumunun takibi harekeli metinlerde daha kolaydır çünkü Kartallıŏ̆lu'nun da ifade ettiği gibi "Arap harfli metinlerdeki imla kalıplaşması, bu alfabenin bırakıldığı tarihe kadar devam etmiş; dil tarihi içinde meydana gelen değişmeler, Arap harfli imlaya çok az yansımıştır." (2011, s. 19). Hāzzā Kitāb$\imath$ Sarf-ı Türkî’de kimi sözcüklerin harekeli yazıldığı ve okutucu ünlülerle kullanıldığı ve yer yer kalıplaşmış imlaya değil söyleyişe (telaffuz) yer verildiği için eserdeki dudak uyumuna uygun

örnekler dikkat çekicidir. Örneğin10a/01'deki turşucular

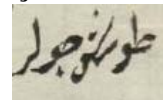
ve örücüler

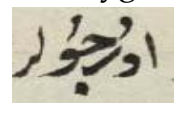
sözcükleri yazarın dönemin söyleyiş özelliklerini de aktardığını düşündürmektedir çünkü Osmanlı Türkçesinde $+c I$ eki imlası kalıplaşmış eklerden biridir. Aynı durum kurd sözcügünün iyelik çekiminde de görülmektedir:

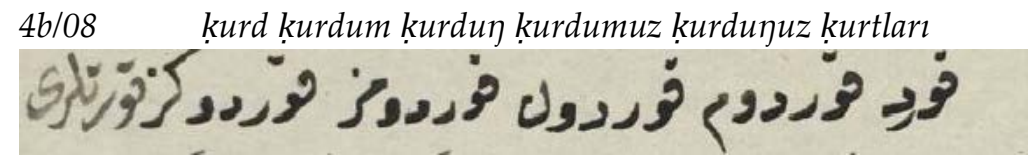

Yine ko- 5a/08 ve dur- 5a/10 fiillerinin kişilere göre görülen geçmiş zaman çekimi de eserde yer yer söyleyişin esas alındığını göstermektedir:

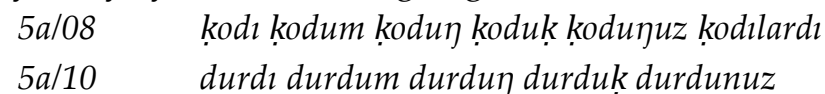

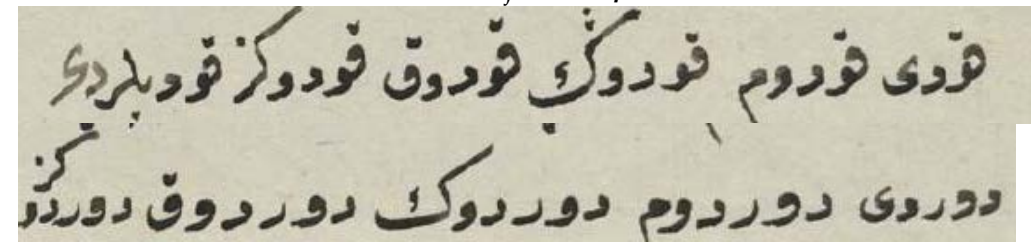

Metinde görülen geçmiş zamanın 3. teklik/çokluk çekiminin yuvarlak tabanlardan sonra hep düz ünlülü olduğu görülmektedir ancak görülen geçmiş zaman ekinin diğer kişi çekimlerinde "geçiş-uyum özelliği" görülmektedir. Eserin şekil bilgisi özelliklerinin incelendiği bölümden anlaşılacağı üzere dudak uyumuna aykırı kullanımlar da fazladır Bu durum yazarın eski yazı geleneğine uyarak yazmasına da bağlanabilir:

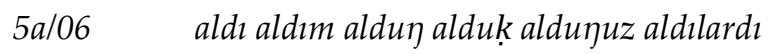

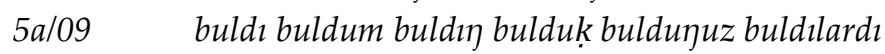




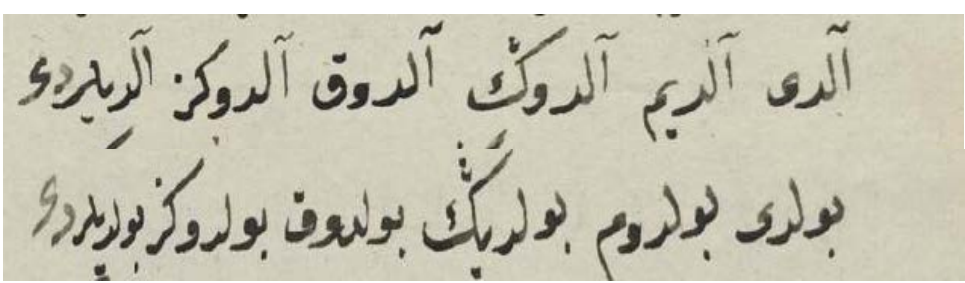

Ünsüz Uyumu: Hāzā Kitāb-ı Sarf-ı Türkî'de ünsüz uyumunu konu alan ekler ilk seslerine göre C, $\mathrm{D}$ sınıfındadır. Metinde geçen $+\mathrm{cI}$ isimden isim yapma eki ünsüz uyumuna uymamaktadır. Tonlu ve tonsuz tabanlardan sonra hep cim (ج) ile yazılmıştır. D sınıfı ekler ise daima (د) ile yazılmıştır dolayısıyla tonsuz tabanlardan sonra ünsüz uyumuna uyulmadığı görülmektedir. Bununla birlikte bazı sözcüklerde (د) harfi üzerine şedde konulmuştur:

5a/05 gitdi gitdim gitdin gitdik gitdiniz gitdilerdi

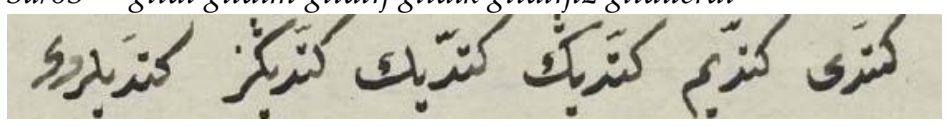

Buradaki git- fiilindeki gibi (د) harfi üzerine şedde konulması tonsuz tabanlardan sonra ünsüz

uyumuna bir işaret olarak yorumlanabilir. Çık- fiilinde ise şedde kullanılmamıştır:

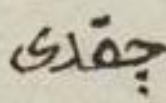

Bildirme ekinde de tonsuz tabanlardan sonra ünsüz uyumuna uyulmamıştır:

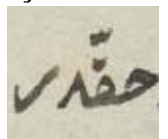

Ünlü değişmeleri: 18. yüzyıl ilk hecedeki /i/ fonemlerinin /è/'ye dönüştüğü bir dönemdir.

Ancak metinde vir- 5a/07 fiili ye (ى) ile yazıldığı ve üstün veya esre ile harekelenmediği için /i/'li okunmuştur:

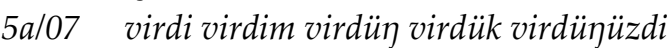

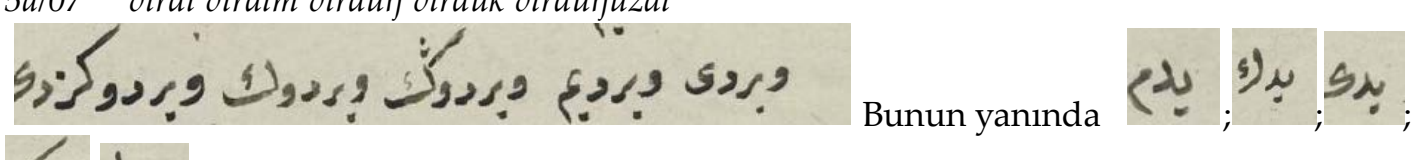

- Id

(yedik yediniz yedi yedik yedim) şeklinde yazılan ye-fiili /e/'li okunmuştur.

Ünsüz değişmeleri: Metindeki düzenli ünsüz değişmeleri dişında dikkati çeken $\mathrm{t}->\mathrm{d}-$ ve -r->-1değişimidir. Metindeki dörpüciler 10/07, damkacılar 9b/06 gibi sözcükler $\mathrm{t}->\mathrm{d}-$ değişimini örneklemektedir. Bununla birlikte metinde ön seste $\mathrm{t}$ - ünsüzünün korunduğunu gösteren țon 3b/01, temürciler 9a/01, țaşcılar 8b/06, tuzcılar 8b/06, tökmeciler 10a/07 gibi sözcükler de vardır. Metin içerisinde aynı kelimenin /t/ ' 'li ve /d/'li şekillerinin bir arada kullanımına rastlanmamıştır. Metinde -r->-1- değişimini yalnızca kelesteciler 9b/02 sözcüğü örneklemektedir.

\subsection{3. Şekil bilgisi}

1.3.3.1. İsim çekim ekleri :

Çokluk eki: Eserin 8b-10a arasındaki varaklarında sıralanan 18. yüzyıl İstanbulu'nun meslek isimlerinin tamamı çokluk eki almıştır:

+lar, +ler: șarāclar 8b/03, ipekciler 9a/06...

Hal ekleri

+a: atlara $3 \mathrm{~b} / 06$.

+da: zamānda $7 \mathrm{~b} / 02,7 \mathrm{~b} / 05$. 


\section{Bildirme ekleri :}

+dır, +dir: güzeldir 6a/02, dilberdir 6a/03, bāğdır 6a/09, hakkdır 6a/09.

İyelik ekleri: Eserin başında yalın halleri verilen isimlerin iyelik çekiminde düzensizlikler olduğu göze çarpmaktadır. Örneğin $4 \mathrm{~b} / 04$ arslan sözcüğünün iyelik çekimi sıralanırken 3 . çokluk kişi çekimi unutulmuştur. Bunun yanında isimlerin iyelik çekimi yapılırken 3. teklik kişi çekimine yer verilmemiştir. Ayrıca kimi sözcüklerde iyelik çekimi yapılırken kişi sırasına uyulmadığı görülmektedir:

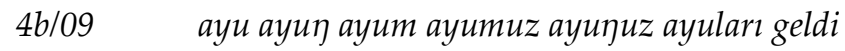

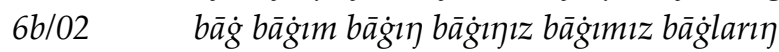

+(1)m, +(i)m, +(u)m, +(ü)m: şam'dānım 2b/01, gözüm 6a/04, ibrïgim 2b/06, kurdum 4b/08, papucum 3b/04, öküzüm 4b/01, țūtum 5a/02.

(Dudak uyumuna uymayan sözcük: kapudım 3a/07).

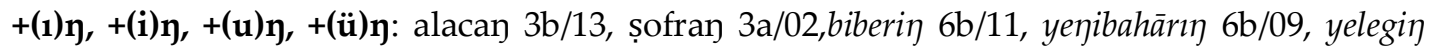
3a/12, paрисиך 3b/04, gögsǖ 6a/08.

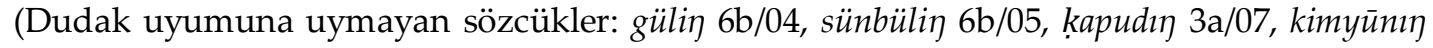
6b/10, öküzi门 4b/01).

+1: eșnāfi 8b/02 ve +si, +si, +su, +sü: senāsı 7b/06.

+(1) miz, +(i)miz, +(u)muz, +(ü)müz: çizmemiz 3b/05, devemiz 4b/03kaymağımı 5b/01, cevizimiz 5b/06, göğsümüz 6a/08, kurdumuz 4b/08.

(Dudak uyumuna uymayan sözcükler: bülbülimiz 4b/12, öküzimiz 4b/0, horuzımız 4a/04, papucımız 3b/04, kapudımız 3a/07).

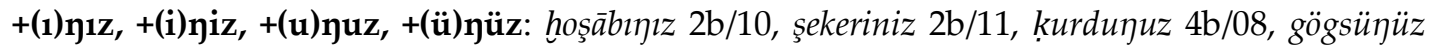
$6 \mathrm{a} / 08$

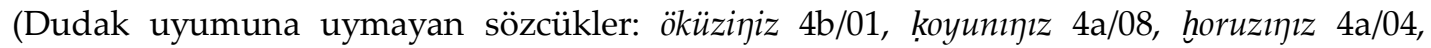

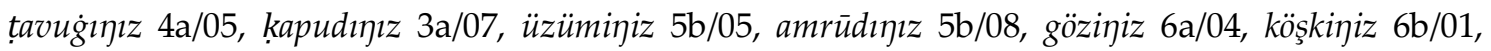

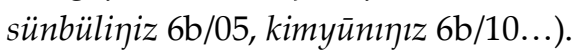

+ları: şam 'dānları 2b/02, șuları 2b/09, şekerleri 2b/11, eșnāfları 8b/01.

\subsubsection{Fiil çekim ekleri:}

Şekil ve zaman ekleri

Haber kipleri

Metinde haber kiplerinin geniş zaman, gelecek zaman, görülen geçmiş zaman örneklerine rastlanmıştır.

\section{Görülen geçmiş zaman eki}

-dım, -dim, -dum, -düm: aldım 5a/06, gitdim 5a/05, kodum 5a/08, döndüm 5a/12. Olumsuzu: sevmedim $8 \mathrm{a} / 03$.

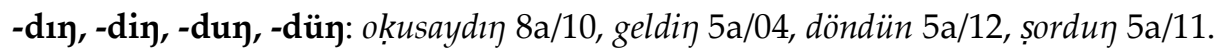

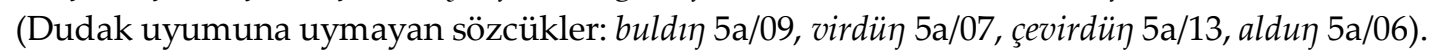

-d1, -di, -du, -dü: geldi 2a/01, gitdi 2a/01, aldı 2a/01, virdi 2a/01, kodı 2a/01, kordı 2a/01, buldı 2a/02, durdı 2a/02, șordı 2a/02, döndi 2a/02, çıkdı 2a/02, çevirdi 2a/03.

-duk, -dik, -duk, -dük: çevirdik 5a/13, bulduk 5a/09, döndük 5a/12, okusaydık 8a/10.

(Dudak uyumuna uymayan sözcükler: alduk $5 \mathrm{a} / 06$, virdük $5 \mathrm{a} / 07$ ).

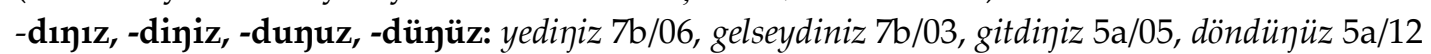

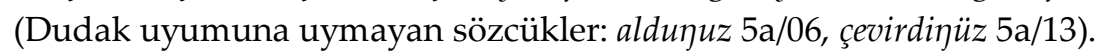

-diler: yediler $7 \mathrm{~b} / 06$, içdiler $7 \mathrm{~b} / 06$. 


\section{Geniş zaman:}

-ar, -er: korkarim 8a/02, severim 8a/02.

Olumsuzu: sevmem 8a/03, sevmezim 8a/03.

\section{Gelecek zaman}

-iser, -1sar: seviserim 8a/02.

-se gerek: sevsem gerek $8 \mathrm{a} / 02$.

-ecek, -acak: sevecegim 8a/02.

\section{Tasarlama kipleri}

Metinde tasarlama kiplerinden emir kipi çekiminin örneklerine rastlanmıştır.

\section{Emir kipi:}

-sin, -sin, -sun, -sün: gelsin $2 \mathrm{~b} / 04$, gelsün $2 \mathrm{~b} / 06$, 3a/01, berekāt virsin $7 \mathrm{~b} / 07$, ziyāde olsun $\mathrm{7b} / 08$

-elim: binelim 3b/06, içelim 2b/05, yiyelim 2b/08, giyelim 3a/07.

Fiillerin birleşik çekimleri

\section{Görülen geçmiş zamanın hikâyesi}

geldim idi $7 \mathrm{~b} / 01$, geldin idi $7 \mathrm{~b} / 01$, geldik idi $7 \mathrm{~b} / 01$, geldinizdi $7 \mathrm{~b} / 01$, geldiler idi $7 \mathrm{~b} / 02$, yedim idi $7 \mathrm{~b} / 04$, sevdim idi 8a/01.

Olumsuzu: yemedin idi $7 \mathrm{~b} / 04$, yemedi idi $7 \mathrm{~b} / 04$, yemedilerdi $7 \mathrm{~b} / 04$, sevmedim idi $8 \mathrm{a} / 04$, sevmedim idi 8a/06, sevmediๆ idi 8a/06, sevmedik idi 8a/06, sevmedilerdi 8a/06.

\section{Geniş zamanın hikâyesi}

güzzel olurdı $7 \mathrm{~b} / 03$, sever idim $8 \mathrm{a} / 01$, eyü olurdı $8 \mathrm{a} / 10$.

Olumsuzu: sevmezdim 8a/03, 8a/04, sevmez idim 8a/07, sevmez idin 8a/07, sevmez idik 8a/07, sevmezler idi 8a/07.

\section{Gelecek zamanın hikâyesi}

sevecek idim 8a/01, 8a/09, sevecek idin 8a/09, sevecek idik 8a/09, seveceklerdi 8a/10.

Olumsuzu: sevmeyecektim 8a/03, sevmesem gerek idi 8a/08, sevmesen gerek idi 8a/08, sermesek gerek idi 8a/08, sevmeseler gerek idi 8a/09.

\section{Şart kipinin hikâyesi}

gelseydim $7 \mathrm{~b} / 02$, gelseydin $7 \mathrm{~b} / 02$, gelseydik $7 \mathrm{~b} / 03$, gelseydiniz $7 \mathrm{~b} / 03$, gelselerdi $7 \mathrm{~b} / 03$, sevsem idi 8a/01, sevseydim 8a/05, sevseydin 8a/05, sevseydik 8a/05, sevseydiniz 8a/05, sevselerdi 8a/05, okusaydım 8a/10, okusaydı 8a/10, okusaydık 8a/10, okusalardı 8a/10.

\section{Gereklilik kipinin hikâyesi}

sevmem gerek idi $8 \mathrm{a} / 04$.

\subsubsection{Yapım ekleri}

+c1, +ci, +cu, +cü: țurşucular 10a/01, örücüler 10a/01, abācllar 9a/01, desdereciler 9b/02.

(Bunun yanında dudak uyumuna uymayan örnekler çok fazladır: pabuccı 8b/02, bārūtcılar 9a/02, țavukcılar 9b/10, topclar 10a/05, tuzcılar 8b/06, yog்urtcılar 9b/01, dörpüciler 10/07...).

\section{Metin}

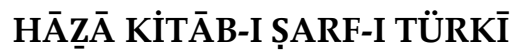

1b/01 ̧̧am ' dān miḳrāṣ mūm çubuk ibrīk

1b/02 ḳahve māşa şerbet ḩoşāb şeker tuz

1b/03 ekmek panayır șofra ḳaşıł bıçak ḳılıc

1b/04 tüfenk ḳaput biniş kürk ḳaftān

1b/05 entāri yelek gömlek țon çaksşır

1b/06 mest pabuc çizme at rāḩt bāhnt

1b/07 yemānī yağlı̣̣ peşkir çuḳa alaca abā

1b/08 kebe kedi ḩoruz tavuḳ ḳaz ördek 
1b/09 ḳoyun ḳuzu keçi manda ḳatır eşek

1b/10 öküz ḳıșrag deve arslan ḳaplan

1b/11 tilki köpek kurd ayu țavşan keklik

1b/12 bülbül serçe ḳanarya țūṭi ḳumrı şāhin

2a/01 geldi gitdi aldı virdi ḳodı ḳordı

2a/02 buldı durdı șordı döndi çıł̣dı

2a/03 çevirdi süd ḳaymak yag bal incīr

2a/04 üzüm ceviz alma amrūd nār kiras

2a/05 ayva erik ḳaysı şeftāli el ayak

2a/06 göz ḳulaḳ baş arḳa gögüs ag̉ız

2a/07 ev ḳonak çādır köşk bāg bāggçe

2a/08 gül sünbül lāle ḳaranfil zencebīl yenibahār

2a/09 kimyūn biber dārçīn sināmekī dār-ı fülfül besbāse

2a/10 kebābiyye ḳardaş ḳanı 'ūdü'l-ḳaḩr ḳalem-i cengār ḳaḳūle çivit

2a/11 kükürt ḳırmız loṭūr māżı rastıḳ nışādır

2a/12 göz țaşı Hindüstān cevizi za ferān günlik

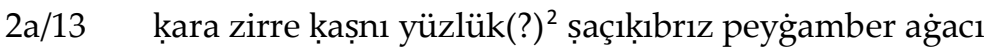

2b/01 şam 'dān benim şam 'dānım şam 'dānın şam 'dānımız şam 'dānınız

2b/02 ̧̧am 'dānları miḳrāṣ miḳrāṣım miḳrāṣın miḳāṣımız miḳrāṣınız miḳrāṣları

2b/03 mūm mūmum mūmun mūmumuz mūmunuz mūmları yandı

2b/04 çubuk çubugium çubugiun çubugiumuz çubugiunuz çubuḳları gelsin

2b/05 tütün tütünüm tütünün tütünümüz tütününüz tütünleri içelim

2b/06 ibrịk ibrìg̀ım ibrìgın ibrìgımız ibrīg̀ınız ibrīkleri gelsün

2b/07 ḳahve ḳahvem ḳahven ḳahvemiz ḳahveniz ḳahveleri içelim

2b/08 ța ām ța 'āmım ța āmın ța āmımız ța'āmınız ța 'āmları yiyelim

2b/09 șu șuyum șuyun șuyumuz șuyunuz șuları içelim

2b/10 hoşāb hoşābım ḩoşābın ḩoşābımız ḩoşābınız ḩoşābları

2b/11 şeker şekerim şekerin şekerimiz şekeriniz şekerleri geldi

$2 b / 12$ tuz tuzum tuzın tuzımız tuzınız tuzları geldi

$2 \mathrm{~b} / 13$

$3 \mathrm{a} / 01$

$3 \mathrm{a} / 02$

$3 a / 03$

$3 \mathrm{a} / 04$

$3 a / 05$

$3 a / 06$ ekmek ekmegim ekmegin ekmegimiz ekmeginiz ekmekleri yiyelim panayır panayırım panayırın panayırımız panayırınız panayırları gelsün șofra șofram șofran șoframız șofrayız șofralar[1] geldi

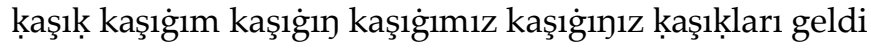
bıçak bıçaġım bıçaġın bıçaġımız bıçaġınız bıçaḳları geldi ḳılıc ḳılıcım ḳılıcın ḳılıcımız ḳılıcınız ḳılıçarı geldi tüfenk tüfengim tüfengin tüfengimiz tüfenginiz tüfenkleri

$3 a / 07$

$3 \mathrm{a} / 08$

$3 a / 09$

$3 a / 10$

$3 a / 11$

$3 a / 12$

$3 a / 13$ ḳaput ḳapudım ḳapudın ḳapudımız ḳapudınız ḳapudları giyelim biniş binişim binişin binişimiz binişiniz binişleri giyelim kürk kürküm kürkün kürkümüz kürkleri giyelim ḳaftān ḳaftānım ḳaftānın ḳaftānımız ḳaftānınız ḳaftānları entāri entārim entārin entārimiz entāriniz entāriler[i] yelek yelegim yelegin yelegimiz yeleginiz yelekler[i] giyelim gömlek gömlegim gömlegin gömlegimiz gömleginiz gömlekleri giyelim

2 Yüzlük (TDK, Tarama Sözlüğü̈, https://sozluk.gov.tr/) anlamlarının yanı sıra "ekmek fırınına atılan odun, bir çocuk oyunu, kılıf" (TDK, Derleme Sözlüğ̈̈, https://sozluk.gov.tr/) anlamları vardır. Metinde yüzlük sözcüğü bitki adları içinde sayıldığı için yüzerlik/üzerlik sözcügünün bir varyantı olabilir. Nitekim DS'de üzerlik sözcüğünün diğer karşılıkları “ilezik, üzellik, üzerik, üzerlik, üzerrik, üzerriyh, yüzerlik, yüzellik” şeklindedir. 
3b/01 țon țonum țonun țonumuz țonunuz țonlar[1] giyelim

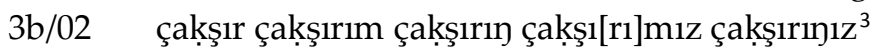

3b/03 mest mestim mestin mestimiz mestiniz mestleri giyelim

3b/04 papuc papucum papucun papucımız papuçları giyelim

3b/05 çizme çizmem çizmen çizmemiz çizmeniz çizmeler[i] giyelim

3b/06 at atım atın atımız atııız atlara binelim

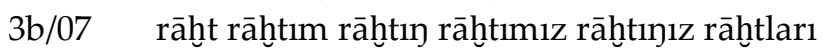

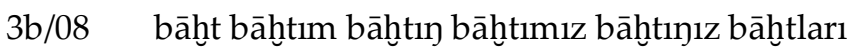

3b/09 yemānī yemān[ī]m yemān[ī]n yemān[ī] miz yemān[ī]niz yemānīleri giyelim

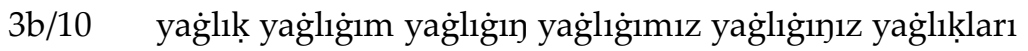

3b/11 peşkir peşkirim peşkirin peşkirimiz peşkiriniz peşkirleri

3b/12 çuḳa çuḳ[a]m çuḳ[a]n çuḳamız çuḳanız çuḳaları

3b/13 alaca alac[a]m alac[a]n alacamız alac[a]yız alacaları

4a/01 abā abām abān abānız abāmız abāları giyelim

4a/02 kebe keb[e]m keb[e]n kebemiz kebeniz kebeleri geldi

4a/03 kedi kedim kedin kedimiz kediniz kedileri geldi

$4 a / 04$ horuz horuzum horuzun horuzımız horuzınız ${ }^{4}$

4a/05 tavuk tav[ugiu]m tav[ugiu]n țavugiumuz țavugìnız țavukları

4a/06 ḳaz ḳazım ḳazıı ḳazımız ḳazınız ḳazları yiyelim

4a/07 ördek ördegim ördegin ördegimiz ördekler[i]

4a/08 koyun ḳoyunum ḳoyunun koyunumuz ḳoyunınız ḳoyunlar[1] yiyelim

4a/09 ḳuzı ḳuz[u]m ḳuzun ḳuzumuz ḳuzınız ḳuzılar[1] yiyelim

4a/10 keçi keçim keçimiz keçiniz keçileri geldi gitdi

4a/11 manda mandam manday mandamız mandanız mandalar[1]

4a/12 kaț̣r ḳațırım ḳațırın ḳațırımız ḳațırınız ḳațırları

4a/13 eşek eşegim eşegin eşegimiz eşeginiz eşekleri

4b/01 öküz öküzüm öküzin öküzimiz öküziniz ${ }^{5}$

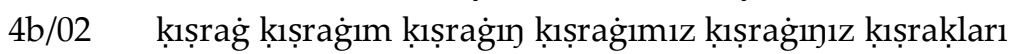

$4 \mathrm{~b} / 03$ deve devem deven devemiz deveniz develer[i] geldi

$4 \mathrm{~b} / 04 \quad$ arslan arslanım arslanın arslanımız arslanınız ${ }^{6}$

4b/05 ḳaplan ḳaplanım ḳaplanın ḳaplanımız ḳaplanınız ḳaplanları

4b/06 tilki tilkim tilkin tilkimiz tilkiniz tilkileri geldi

4b/07 köpek köpegim köpegin köpegimiz köpeginiz köpekleri

4b/08 kurd ḳurdum ḳurdun kurdumuz ḳurdunuz ḳurtları

$4 \mathrm{~b} / 09$ ayu ayun ayum ayumuz ayunuz ayuları geldi

4b/10 țavşan țavşanım țavşanın țavşanımız țavşanınız țavşanları

4b/11 keklik kekligim kekligin kekligimiz kekliginiz keklikleri

$4 \mathrm{~b} / 12$ bülbül bülbülüm bülbülün bülbülimiz bülbüliniz bülbüller[i] geldi

$4 \mathrm{~b} / 13$ serçe serçem serçen serçemiz serçeniz serçeleri

5a/01 ḳanarya ḳanaryam ḳanaryan ḳanaryamız ḳanaryanız ḳanaryalar[1] geldilerdi

5a/02 țūṭi ṭūṭum țūṭun țūtīmiz țūtīiziz țūtīleri geldi

5a/03 şāhin şāhinim şāhinin şāhinimiz şāhininiz şāhinleri

$5 \mathrm{a} / 04 \quad$ geldi geldim geldin geldik geldiniz geldiler idi ammā

$5 \mathrm{a} / 05 \quad$ gitdi gitdim gitdin gitdik gitdiniz gitdilerdi

\footnotetext{
${ }^{3}$ Bu satırda çakş̧ır sözcüğünün 3. çokluk iyelik çekimi çakşırları unutulmuştur.

${ }^{4}$ Bu satırda horuz sözcüğünün 3. çokluk iyelik çekimi horuzları unutulmuştur.

${ }^{5}$ Bu satırda öküz sözcüğünün 3. çokluk iyelik çekimi öküzleri unutulmuştur.

${ }^{6}$ Bu satırda arslan sözcügüünün 3. çokluk iyelik çekimi arslanları unutulmuştur.
} 
5a/06 aldı aldım aldun alduk aldunuz aldılardı

$5 a / 07 \quad$ virdi virdim virdün virdük virdünüzdi

5a/08 kodı ḳodum kodun ḳoduk ḳodunuz ḳodılardı

5a/09 buldı buldum buldın bulduk buldunuz buldılardı

$5 \mathrm{a} / 10 \quad$ durdı durdum durdun durduk durdunuz ${ }^{7}$

5a/11 șordı șordum șordun șorduk șordunuzdı ${ }^{8}$

$5 a / 12$ döndi döndüm döndün döndük ${ }^{9}$ döndünüz döndiler

$5 \mathrm{a} / 13$ çevirdi çevirdüm çevirdün çevirdik çevirdinüz ${ }^{10}$

5b/01 ̣aymaḳ ḳaymaġım ḳaymaġın ḳaymaġımız ḳaymaġınız ḳaymaḳları

$5 \mathrm{~b} / 02$ yag் yaġım yaġın yaġımız yaġınız yag்ları

5b/03 bal balım balıy balımız balını balları geldi

$5 \mathrm{~b} / 04 \quad$ incīr incūrim incūrin incūrimiz incūriniz incürleri

5b/05 üzüm üzümüm üzümün üzümimiz üzüminiz ${ }^{11}$

$5 b / 06$ ceviz cevizim cevizin cevizimiz ceviziniz cevizleri

$5 \mathrm{~b} / 07 \quad$ alma almam alman almamız almanız almaları geldi

$5 \mathrm{~b} / 08$ amrūd amrūdum amrūdın amrūdımız amrūdınız ${ }^{12}$

5b/09 nār nārım nārın nārımız nārınız nārlar[1] geldi

5b/10 kiras kirasım kirasın kirasımız kirasınız kirasları

$5 b / 11$ ayva ayvam ayvan ayvamız ayvanız ayvalar[1] geldi

$5 b / 12$ erik erigim erigin erigimiz eriginiz eriḳleri

5b/13 ḳaysı ḳaysım ḳaysın ḳaysımız ḳaysınız ḳaysıları

6a/01 şeftāli şeftālim şeftālin şeftālimiz şeftāliniz şeftālileri yiyelim

6a/02 el elim elin elimiz eliniz elleri geldi güzeldir

6a/03 ayak ayag்ım ayag்ın ayag்ımız ayaġınız ayaḳları dilberdir

6a/04 göz gözüm gözin gözimiz göziniz gözler[i] gördilerdi

6a/05 ḳulak ḳulaġım ḳulaġın ḳulaġımız ḳulaġınız kulaḳları işitdi

6a/06 baş başım başın başımız başııız başları maḥbūb

6a/07 arḳa arḳam arḳan arḳamız arḳanız arḳaları dilber

6a/08 gögüs gögsüm gögsün gögsümüz gögsünüz gögüsleri bāg̉dır

6a/09 ag்ız ag்zım ag̉zın aǵzımız aǵzııız aġızları ḥaḳdır

6a/10 ev evim evin evimiz eviniz evleri buldılard 1

6a/11 ḳonag ḳonaġım ḳonaġın ḳonaġımız ḳonaġııı ḳonaġları

6a/12 çārdak çārdagiım çārdagiın çārdagiımız çārdagiınız ${ }^{13}$

6a/13 çādır çādırım çādırın çādırımız çādırııız çādırları

6b/01 köşk köşküm köşkin köşkimiz köşkiniz köşkleri

6b/02 bāg bāġım bāg̀ın bāğınız bāg̀ımız bāğları

6b/03 bāg̣çe bāgçem bāg̣çen bāg̣çemiz bāg̣çeniz bāg̣çeleri

$6 \mathrm{~b} / 04$ gül gülüm gülin gülimiz güliniz gülleri

6b/05 sünbül sünbülüm sünbülin sünbülimiz sünbüliniz sünbülleri

7 Bu satırda dur- fiilinin görülen geçmiş zaman 3. çokluk şahıs çekimi durdılar unutulmuştur.

8 Bu satırda sor- fiilinin görülen geçmiş zaman 2. çokluk çekimi sorduñuz yerine görülen geçmiş zamanının hikâye 2. çokluk çekimi şorduñuzdı verilmiş; sonrasında 3. çokluk şahıs çekimi sordılar unutulmuştur.

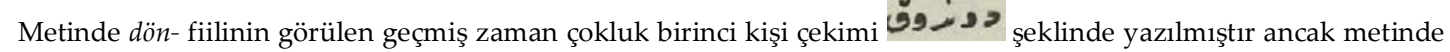
görülen geçmiş zaman çokluk birinci kişi çekimi bu sözcük dişında damak uyumuna uygundur, bu da sözcüğ̈ün sehven böyle yazıldı̆̆ını göstermektedir.

10 Bu satırda çevir- fiilinin görülen geçmiş zaman 3. çokluk şahıs çekimi çevirdiler unutulmuştur.

11 Bu satırda üzüm sözcüğ̈̈nün 3. çokluk iyelik çekimi üzümleri unutulmuştur.

12 Bu satırda amrūd sözcüğünün 3. çokluk iyelik çekimi amrūdları unutulmuştur.

13 Bu satırda çārdak sözcüğünün 3. çokluk iyelik çekimi çārdakları unutulmuştur. 
6b/06 lāle lālem lālen lālemiz lāleniz lāleleri

6b/07 ḳaranfil ḳaranfilim ḳaranfilin ḳaranfilimiz ḳaranfiliniz ḳaranfilleri

6b/08 zencebīl zencebīlim zencebīlin zencebīlimiz zencebīliniz zencebīlleri

6b/09 yenibahār yenibahārım yenibahārın yenibahārımız yenibahārınız ${ }^{14}$

6b/10 kimyūn kimyūnum kimyūnın kimyūnımız kimyūnınız kimyūnları

6b/11 biber biberim biberin biberimiz biberiniz biberler biberleri

6b/12 dārçīn dārçīnim dārçīnin dārçīnimiz dārçīniniz dārçīnları

6b/13 'anber 'anberim 'anberin 'anberimiz 'anberiniz 'anberleri

$7 \mathrm{a} / 01$ günlik günlik günlik günligim günligin günligimiz ${ }^{15}$ günlükleri

$7 a / 02 \quad$ yüzerlik yüzerligim yüzerligin yüzerligimiz ${ }^{16}$ yüzerlikleri

7a/03 minder yașdı̣ yorgan çārşaf seccāde kilim ḥalı

7a/04 şāl ḳuşaḳ șarıḳ duvaḳ ḳalem ḳalemtıraş kāğı̀t

7a/05 minder minderim minderin minderimiz minderiniz minderleri

7a/06 yașdıḳ yașdığım yașdıġın yașdı́̆ımız yașdığınız yașdıḳları

$7 \mathrm{a} / 07$ yorgan yorganım yorganın yorganımız yorganınız yorganları

7a/08 çārşaf çārşafım çārş̧afın çārş̧afımız çārşafınız çārş̧afları

7a/09 seccāde seccādem seccāden seccādemiz seccādeniz seccādeleri

7a/10 şāl şālım şālın şālımız şālııız şāllar şālları

7a/11 ̣uşaḳ ḳuşaġım ḳuşag̉ın ḳuşaġımız ḳuşaġınız ḳuşaḳları

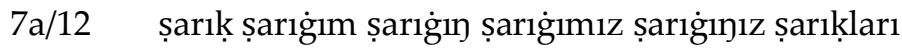

7a/13 ḳalem ḳalemim ḳalemin ḳalemimiz ḳaleminiz ḳalemlerimiz ḳalemleriniz kesildi

$7 \mathrm{~b} / 01 \quad$ geldim idi geldin idi geldik idi geldinizdi

7b/02 geldiler idi geçmiş zamānda gelseydim gelseydin

$7 \mathrm{~b} / 03 \quad$ gelseydik gelseydiniz gelselerdi güzel olurdı

$7 \mathrm{~b} / 04$ ța ām yedim idi yemedin idi yemedi idi yemedilerdi

7b/05 geçmiş zamānda yedim içdim yedin içdin yedi içdi

$7 \mathrm{~b} / 06$ yedik içdik yediniz içdiniz yediler içdiler senāsı

7b/07 berekāt virsin 1201 hārr(?) $)^{17}$

$7 \mathrm{~b} / 08$ ziyāde olsun

7b/09 Seveddehü İbrāhim Efendi

8a/01 sevdim idi sevecek idim sevsem idi sever idim

8a/02 severim seviserim sevsem gerek sevecegim ammā ḳorḳarım

8a/03 sevmem sevmezim sevmedim sevmezdim sevmeyecekdim

8a/04 sevmedim idi sevmezdim sevmem gerek idi ammā

$8 \mathrm{a} / 05 \quad$ sevseydim sevseydin sevseydik sevseydiniz sevselerdi

8a/06 sevmedim idi sevmedin idi sevmedik idi sevmedilerdi

8a/07 sevmez idim sevmez idin sevmez idik sevmezler idi

8a/08 sevmesem gerek idi sevmesen gerek idi sevmesek gerek idi

8a/09 sevmeseler gerek idi sevecek idim sevecek idin sevecek idik

8a/10 seveceklerdi oḳusaydım oḳusaydın oḳusaydıḳ oḳusalardı eyü olurdı

8b/01 Bāb u Fī Beyān-ı Eșnāfları

8b/02 terzī eṣnāı̊ debbāg eṣnāfı pabuccı eșnāfı

14 Bu satırda yeñibahār sözcüğünün 3. çokluk iyelik çekimi yeñibahārları unutulmuştur.

15 Bu satırda günlik sözcüğünün 2. çokluk iyelik çekimi günligiñiz unutulmuştur.

16 Bu satırda yüzerlik sözcügünün 2. çokluk iyelik çekimi yüzerligiñiz unutulmuştur.

17

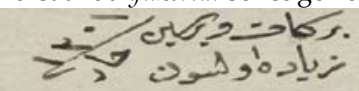

kökenli ḥār "sıcak, hararetli" anlamına gelmektedir. 
8b/03 yemenīci eșnāfı nalbant eșnāfı șarāclar eșnāfı

8b/04 keçeciler eșnāfı ḥallāclar leblebīciler şekerciler

8b/05 ḳuru yemişciler beyzciler yumurțacılar bal mūmcılar

8b/06 tekneciler eșnāfı țaşcılar eșnāfı tuzcılar zeytūnyağcılar

8b/07 pirincciler arpacılar duhāncılar kömürciler kayıḳ̣cılar

8b/08 limoncılar șābūncılar bakkkallar ḳașṣāblar balıḳcılar eșnāfı

9a/01 duhān ḳıyıcılar bıçaḳ[çı]lar ḳılıccı ḳıncılar temürciler

9a/02 ḳanțarcılar ḳundaḳcılar bārūtcılar nalçacılar boyacılar

9a/03 eskiciler aşcılar bacacılar doğramacılar ḳafesciler ḳuṭucılar

9a/04 ḩaffāflar fesciler nalburlar berberler sā atciler eșnāfı

9a/05 taḩmīsciler ḳavurcı[lar] dugùūcılar kettāncılar hasṣırcılar

9a/06 ḥalıcılar yorgancılar bașmacılar boyacılar ipekciler eșnāfı

9a/07 baḳırcılar ḳazāncılar çarḳcılar ḳalaycılar pambukcılar eșnāfı

9a/08 pașdırmacılar yaġcılar ḳavuḳcılar ḳolțuḳcılar oturaḳcılar

9a/09 çaḳmaḳcılar maḳascılar eșnāfı dügmeciler ḳabuḳcılar ḳolancılar ḳuşaḳcılar

9a/10 çuḳacılar abacılar iplikciler ipciler ekmekciler börekciler

9b/01 çörekciler gözlemeciler ḳadāyıfcılar ḥelvācılar yoġurtcılar

9b/02 dülgerler naḳḳāşlar kelesteciler kiremitciler kerpicciler

9b/03 tenekeciler şisşeciler cāmcılar aynacılar igneciler

9b/04 imāmeciler çubuḳcılar parmaḳcılar örekeciler tülbentciler

9b/05 filcāncılar kilitciler ḥānı șafrancılar șābūncılar șandıḳcılar

9b/06 țaraḳcılar lüleciler ḳazzāzlar bezzāzlar ḳașṣarlar damḳacılar

9b/07 terlikciler bozacılar şerbetciler ḳahveciler kebābcılar

9b/08 ḩoşābcılar pekmezciler zeytūncılar degirmenciler keşkekciler

9b/09 divīdciler kāğıțcılar mürekkebciler fenerciler örekçiler (? $)^{18}$

9b/10 țavukçclar arabacılar çömlekciler ḳașșāblar cigerciler simitciler

9b/11 keserciler desdereciler çırbıcılar ḩorașāncılar sebzevātcılar

10a/01 țurşucular sirkeciler bedesden șaḥhāflar örücüler tācirler

10a/02 esīrciler yașdıḳcılar ḳılabdāncılar mūṭaflar kürkciler mücellidler

10a/03 mühreciler iskemleciler dıvārcılar cemmāzlar (?) ${ }^{19}$ kirecciler eșnāfı

10a/04 ḥammāllar ḳuṭucılar yine ḳașșāblar kirişciler cigerciler tellāklar

10a/05 ḳumbaracılar țopcılar yag̉lı̣cılar tekyeciler ḳılābdāncılar sepetciler

10a/06 șaraçlar ḳımacılar ḳopçacılar tütün ḳıyıılar pekmezciler ḳalıbcılar

10a/07 ḳalyoncılar tökmeciler dörpüciler egeciler laġımcılar ırḳatlar aḳcılar

10a/08 ḥakkāklar usturacılar tesbiḥciler ḳaşıḳcılar igneciler misvākcılar

10a/09 muhallebciler şālcılar aṣdarcılar aṣbahāa pazarı(?) ${ }^{20}$ șırıkcıllar çorabcılar

10a/10 çarḳcılar ḳarulacılar(?) $)^{21}$ enserciler mūmcılar unḳapancılar vezneciler

10a/11 meyhāneciler küpciler çanaḳcılar çömlekciler filcāncılar eșnāfı

10a/12 ḳubūrcılar mezārcılar bāğcılar bāg̣çevānlar oduncılar șamancılar

18

19

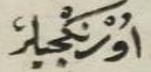

جمتازئ

burada geçen ikinci sözcük yazım hatası yapıldığı düşünülerek pazarı şeklinde okunmuştur.

21 Pakalın, ķarula' yı yakasını direğe veya yakın münasip bir yere bağlamak üzere tertip edilmiş kamçılar şeklinde tanımlamıştır (1993, C. II, s. 284). Karulacıların görevi ile ilgili bir bilgi bulunamamıştır. 
Sözlük

abā (<Ar. 'abā) Yünün dövülmesiyle yapılan kalın ve kaba kumaş.

a. $1 \mathrm{~b} / 07,4 \mathrm{a} / 01$.

abacı Aba satan kimse.

$$
\text { a. } 9 \mathrm{a} / 01
$$

ag̀ız Ağız.
a. $2 \mathrm{a} / 06,6 \mathrm{a} / 09$.

aḳcı Akçı, ipek ve ibrişim iplik (ipek) ve kumaşların rengini açan kimse.
a. $10 \mathrm{a} / 07$

al- Almak
a. $2 \mathrm{a} / 01,5 \mathrm{a} / 06$.

alaca Birkaç renkli iplikten dokunan, genellikle kırmızı zemin üzerine sarı çubuklu, Anadolu'da çok yaygın bir kumaş cinsi.
a. $1 b / 07,3 b / 13$.

alma Elma.

$$
\text { a. } 2 \mathrm{a} / 04,5 \mathrm{~b} / 07 \text {. }
$$

ammā (<Ar.) Ama.

$$
\text { a. } 5 \mathrm{a} / 04,8 \mathrm{a} / 02,8 \mathrm{a} / 04 \text {. }
$$

amrūd $(<$ Far. emrū d) Armut.

$$
\text { a. } 2 \mathrm{a} / 04,5 \mathrm{~b} / 08 \text {. }
$$

'anber (<Ar.) Amber balığından çıkarılan güzel kokulu, kül renginde bir madde.

$$
\text { 'a. 6b/13. }
$$

arabacı 1. Araba yapan sanatkâr. 2. Araba süren kimse.
a. $9 b / 10$

arpacı Arpa ve özellikle hayvan yemi satan kimse. Yem satan, allaf.

$$
\text { a. } 8 \mathrm{~b} / 07 \text {. }
$$

arḳa İnsanın vücudu, bedeni; vücudun belden boyuna kadar olan sirt kısmı.

arslan Aslan.

$$
\text { a. 2a/06, 6a/07. }
$$

$$
\text { a. } 1 b / 10,4 b / 04 \text {. }
$$

aṣbaḥā pazarı (?) a. 10a/09.

așdarcı Astar satan kimse.

$$
\text { a. } 10 \mathrm{a} / 09 \text {. }
$$

aşc1 1. Bir ev veya konakta yemek pişirmekle görevli kimse. 2. Hususi bir dükkânda yemek pişirip para karşılığında satan kimse.
a. $9 \mathrm{a} / 03$.

at At.

a. $1 b / 06,3 b / 06$.

ayak Ayak.
a. $2 \mathrm{a} / 05,6 \mathrm{a} / 03$.

aynacı Ayna yapan veya satan kimse.
a. $9 \mathrm{~b} / 03$.

ayu Ayı.
a. $1 b / 11,4 b / 09$.

ayva Ayva.
a. $2 \mathrm{a} / 05,5 \mathrm{~b} / 11$.

bāb (<Ar.) Kitabın bölümlerinden her biri.

b. $8 \mathrm{~b} / 01$

bacacı Bacacı, baca temizleyen kimse. b. $9 a / 03$

bāg $\quad(<$ Far. $b \bar{a} \dot{g})$ Üzüm kütüklerinin dikili bulunduğu toprak parçası.

b. $2 \mathrm{a} / 07,6 \mathrm{~b} / 02$.

bāġcı Bağ yetiştiren ve üzümünü satan kimse.

b. $10 a / 12$.

bāg̣çe (<Far. $b \bar{a} \dot{g}+c ̧ e)$ Bahçe, Sebze, meyve, çiçek veya ağaç yetiştirilen yer.

b. $2 \mathrm{a} / 07,6 \mathrm{~b} / 02$.

bāg̣çevān (<Far.) Mesleği bahçeye bakmak, çiçek, meyve veya sebze yetiştirmek olan kimse, bağban.

b. $10 \mathrm{a} / 12$.

bāhnt $(<$ Far. baht $)$ Arabaya koşulan hayvanın kayış takımı.

b. $1 \mathrm{~b} / 06,3 \mathrm{~b} / 08$.

baḳkal (< Ar. bakkkāl) Bakkal. b. $8 \mathrm{~b} / 08$.

baḳırcı Bakırdan kaplar yapan sanatkâr. b. $9 a / 07$

bal Bal. b. $2 \mathrm{a} / 03,5 \mathrm{~b} / 03$.

balıḳcı Balıkçı. b. $8 \mathrm{~b} / 08$.

bal mūmcı Bal mumu yapan veya satan kimse.

b. $8 \mathrm{~b} / 05$

bārūtcı 1. Barut yapan. 2. Osmanlı

Devleti'nde barutçu başının gözetiminde baruthanede barut yapan cebeci ocağına bağlı işçi. 
b. $9 a / 02$.

bașmacı 1. Tülbent üzerine kalıp basan kimse. 2. Basma yapan ve satan kimse.
b. $9 \mathrm{a} / 06$

baş Baş, kafa.

b. $2 a / 06,6 a / 06$.

bedesden (<Far. bezzāz-istān) İçinde değerli eşya, antika, mücevher vb. şeyler satılan, üstü kapalı çarşı.

b. $10 \mathrm{a} / 01$.

ben Ben, teklik birinci kişiyi gösteren söz.

b. $2 b / 01$.

berber (<Far.) Saç ve sakal kesmeyi meslek edinmiş kimse.

b. $9 \mathrm{a} / 04$.

berekāt (<Ar.) Bereketler.

b.virsin Allah'a şükürler olsun ki, neyse ki.

b. $7 \mathrm{~b} / 07$.

besbāse (<Ar.) Üzerlik tohumunun beyaz türü.

b. $2 \mathrm{a} / 09$.

beyān (<Ar.) Açıklama.

b. $8 \mathrm{~b} / 01$.

beyzci Yumurtaci.

b. $8 \mathrm{~b} / 05$.

bezzāz (<Ar). Bez ve bezden yapılmış şeyler satan tüccar, manifaturacı. b. $9 \mathrm{~b} / 06$.

biçaḳ Biçak.

b. $1 b / 03,3 a / 04$.

bıçaḳ[çı] Bıçak yapan veya bıçak satan kimse.

b. $9 \mathrm{a} / 01$.

biber $\quad(<$ Yun. pipéri< Sans.Pippali) Biber. b. $2 \mathrm{a} / 09,6 \mathrm{~b} / 11$.

bin- Binmek.

b. $3 b / 06$.

biniş Çok bol ve geniş cüppe, ferâce. b. $1 b / 04,3 a / 08$.

boyacı Boya çeşitlerini hazırlayan ve satan, boyama işi ile uğraşan ve hayatını bununla kazanan adam.

b. $9 a / 02,9 a / 06$.

bozacı Boza yapan ve gezerek boza satan kimse. b. $9 \mathrm{~b} / 07$.

börekci Börek pişirip dükkanında veya sokakta satan kimse.

b. $9 \mathrm{a} / 10$.

bul- Bulmak.
b. $2 a / 02,5 a / 09,6 a / 10$.

bülbül (<Far.) Bülbül.

b. $1 b / 12,4 b / 12$.

cāmcı Camcı, cam ticaretini veya cam takmayı meslek edinmiş kimse. c. $9 \mathrm{~b} / 03$.

cemmāz (?) c. 10a/03.

ceviz (<Ar.) Ceviz. c. $2 \mathrm{a} / 04,5 \mathrm{~b} / 06$.

cigerci 1 . Koyun ve sığır gibi hayvanların ciğer, yürek, böbrek ve bağırsak gibi kısımlarını satan kimse. 2. Yalnız ciğer pişirip satan kimse. c. $9 b / 10,10 a / 04$.

çādır $\quad(<$ Far. çāder $)$ Çadır. ç. 2a/07, 6a/13.

çaḳmaḳcı Çakmaklı silâhların çakmaklarını yapan ve tamir eden kimse. ç. $9 \mathrm{a} / 09$.

çakssır (<Far. çākşūr) Paça bölümü diz üstünde veya diz altında kalan bir tür erkek şalvarı. ç. $1 b / 05,3 b / 02$.

çayaḳcı Çanak yapan veya satan kimse. ç. $10 \mathrm{a} / 11$.

çārdaḳ (<Far. çehār +Ar. țāk) Çardak. ç. $6 \mathrm{a} / 12$

çarḳcı 1. Tekerlekli bileği ile bıçak vb. bileyen kimse. 2. Gemilerde makine bölümünü yöneten kimse. ç. $9 \mathrm{a} / 07,10 \mathrm{a} / 10$.

çārşaf $\quad(<$ Far. çār-şeb) Çarşaf. ç. $7 \mathrm{a} / 03,7 \mathrm{a} / 08$.

çevir- Çevirmek. ç. $2 \mathrm{a} / 03,5 \mathrm{a} / 13$.

çırbıcı Çırpıcı, eskiden sokaklarda beygirle dolaşarak konak ve evlerden kirlenmiş halıları toplayıp yıkayan ve temizleyen kimselere verilen isim, kassar.

ç. $9 \mathrm{~b} / 11$.

çıḳ- Çıkmak.

ç. $2 \mathrm{a} / 02$. 
çivit Çin, Yemen ve Hindistan'da yetişen bir bitkiden elde edilen veya sun'î olarak yapılan mâvi renkli toz boya. ç. $2 \mathrm{a} / 10$.

çizme Çizme.

$$
\text { ç. } 1 b / 06,3 b / 05 \text {. }
$$

çorabcı Çorap ören, çorap yapan veya çorap satan.

$$
\text { ç. 10a/09. }
$$

çömlekci Topraktan çanak, çömlek gibi kaplar yapan veya satan kimse. ç. $9 b / 10,10 a / 11$.

çörekci Çörek yapan veya satan kimse.

$$
\text { ç. } 9 b / 01 \text {. }
$$

çubuk Tütün içmek için kullanılan, ekseri yâsemin, kiraz, gül, pelesenk gibi ağaçlardan yapılan uzun ağızlık.

ç. $1 \mathrm{~b} / 01,2 \mathrm{~b} / 04$.

çubuḳcı 1. Çubuk takımlarının bakımı, tütün temini ve hazırlanması gibi işlere bakan hizmetçi, tütüncü. 2 . Tütün içiminde kullanılan çubukları yapan veya satan kimse.

ç. $9 \mathrm{~b} / 04$.

çuḳa (<Far. çūha) Çuha, yünden dokunmuş, tüysüz, ince ve sık düz kumaş.

$$
\text { ç. } 1 b / 07,3 b / 12 \text {. }
$$

çuḳacı Çuha dokuyan veya satan kimse.

$$
\text { ç. } 9 \mathrm{a} / 10 \text {. }
$$

damḳacı Damgacı, damga vurmakla görevli kimse.

$$
\text { d. } 9 \mathrm{~b} / 06 \text {. }
$$

dārçīn (<Far.) Tarçın. d. 2a/09, 6b/12.

dār-1 fülfül (<Far. dār +Ar. fulful) Tarçın tohumu da denen, karabibere benzer, uzun taneli bir baharat çeşidi.

d. $2 \mathrm{a} / 09$.

debbāg̀ (<Ar.) Deri terbiye eden kimse, tabak, sepici.

d. $8 \mathrm{~b} / 02$.

degirmenci Un değirmeni işleten, un değirmeni çalıştıran kimse. d. $9 \mathrm{~b} / 08$.

desdereci Testereci.

$$
\text { d. } 9 \mathrm{~b} / 11 \text {. }
$$

deve Deve. d. $1 b / 10,4 b / 03$.

dilber (<Far.) Gönlü kendine çeken, güzel. d. 6a/03, 6a/07.

dıvārcı Duvarcı, duvar ören usta.

$$
\text { d. } 10 a / 03 \text {. }
$$

divīdci Divit yapan veya satan kimse.

$$
\text { d. 9b/09. }
$$

doġramacı Yapılarda dülger işi olan kaba ahşap kısımlar dişındaki kapı, pencere, raf vb. ağaç işlerini yapan kimse.

$$
\text { d. } 9 \mathrm{a} / 03 \text {. }
$$

dön- Dönmek.

$$
\text { d. } 2 \mathrm{a} / 02,5 \mathrm{a} / 12 \text {. }
$$

dörpüci Doğrama ve kesme gibi işlerde kullanılan aletleri keskinleştiren, kullanılır hâle getiren.

d. $10 \mathrm{a} / 07$.

dugì̄cı Terayağı yapan ve satan kimse. d. $9 a / 05$.

duhāncı Tütün yetiştiren veya satan kimse. d. $8 \mathrm{~b} / 07$.

duhāan ḳıyıcı Ham tütünü kıyıp satan kimse.
d. $9 \mathrm{a} / 01$.

dur- Durmak.

$$
\text { d. 2a/02, 5a/10. }
$$

duvaḳ Duvak, gelinin başını, bazen de yüzünü örten dantel veya tülden örtü.

d. $7 \mathrm{a} / 04$.

dügmeci Ismarlama düğme yapan veya düğme satan kimse. d. 9a/09.

dülger Yapıların kapı, pencere dışındaki kaba tahta ve ağaç işlerini yapan usta.

d. $9 b / 02$.

egeci Eğeci, ege ile iş gören maden vb. şeyleri eğeleyen kimse. d. 10a/07.

ekmek Ekmek. e. $1 b / 03,2 b / 13$.

ekmekci Ekmek yapan ve gezdirip satan kimse.

el El.

$$
\text { e. } 9 \mathrm{a} / 10 \text {. }
$$

$$
\text { e. } 2 \mathrm{a} / 05,6 \mathrm{a} / 02 \text {. }
$$

encīr $\quad(<$ Far. $)$ İncir. krş. incīr 
e. $5 b / 04$.

enserci Çivici.

e. $10 a / 10$.

entāri (<Ar). Genellikle tek parçalı kadın giyeceği.

e. $1 b / 05,3 a / 11$.

erik bk. erik

e. $2 \mathrm{a} / 05$.

erik $\quad$ Erik. krş. erik

e. $5 b / 12$.

esirci Köle ve cariye alıp satan, bunun ticaretini yapan kimse.

e. $10 \mathrm{a} / 02$.

eskici 1. Eski elbiseler vb. alıp satan

kimse. 2. Eski ayakkabı vb. tamir eden kimse.

e. $9 \mathrm{a} / 03$.

eșnāf (<Ar.) Küçük sermaye ve zanaat sahibi.

e. $8 \mathrm{~b} / 01,8 \mathrm{~b} / 02$ (3), 8b/03 (3),

$8 \mathrm{~b} / 04,8 \mathrm{~b} / 06(2), 8 \mathrm{~b} / 08,9 \mathrm{a} / 04,9 \mathrm{a} / 06$, $9 \mathrm{a} / 07,9 \mathrm{a} / 09,10 \mathrm{a} / 03,10 \mathrm{a} / 11$.

eşek Eşek.

e. $1 b / 09,4 a / 13$.

ev $\quad \mathrm{Ev}$

e. $2 \mathrm{a} / 07,6 \mathrm{a} / 10$.

eyü İyi

e. ol- Yerinde olmak. 8a/10.

fenerci Fenerci, tulumba takımında feneri taşıyan tulumbacı.

f. 9b/09.

fesci Fes yapan veya satan kimse.

f. $9 \mathrm{a} / 04$

fī (<Ar.) İçinde, içine, hakkında, dair. f. $8 \mathrm{~b} / 01$.

filcāncı Fincan ve ona benzer şeyleri yapan veya satan kimse.

f. $9 b / 05,10 a / 11$.

geçmiş Mazi.

g. zamān Mazi. 7b/02.

gel- Gelmek.

g. $2 a / 01,2 b / 04,2 b / 06,2 b / 11,2 b / 12$ $3 a / 01 ， 3 a / 02,3 a / 03 ， 3 a / 04,3 a / 05$, $4 a / 03,4 a / 10,4 b / 03,4 b / 06,4 b / 09$, $4 \mathrm{~b} / 12 ， 5 \mathrm{a} / 01 ， 5 \mathrm{a} / 02 ， 5 \mathrm{a} / 04 ， 5 \mathrm{~b} / 03$, $5 b / 07,5 b / 09,5 b / 11,6 a / 02,7 b / 01$, $7 \mathrm{~b} / 02,7 \mathrm{~b} / 03$. gerek Lazım, icap. (Metinde gereklilik kipi ve -sA gerek kalıbında gelecek zaman işlevindedir) g. $8 \mathrm{a} / 02,8 \mathrm{a} / 04,8 \mathrm{a} / 08,8 \mathrm{a} / 09$.

git- Gitmek.

$$
\text { g. 2a/01, 4a/10, 5a/05. }
$$

giy- Giymek. g. 3a/07, 3a/08, 3a/09, 3a/12, 3a/13, $3 b / 01 ， 3 b / 03 ， 3 b / 04 ， 3 b / 05 ， 3 b / 09$, $4 \mathrm{a} / 01$.

gögüs Göğüs, bağır. g. $2 a / 06,6 a / 08$.

gömlek Gömlek.

g. $1 b / 05,3 a / 13$.

gör- Görmek. g. $6 \mathrm{a} / 04$.

göz Göz. g. $2 a / 06,6 a / 04$.

göz taşı Bakır sülfat. g. $2 \mathrm{a} / 12$.

gözlemeci Gözleme yapıp satan kimse. g. $9 \mathrm{~b} / 01$.

gül $\quad(<$ Far. gul $)$ Gül. g. $2 \mathrm{a} / 08,6 \mathrm{~b} / 04$.

günlik Günlük, günlük ağacının tütsü olarak kullanılan ve nefese rahatlık veren reçinesi. g. $2 \mathrm{a} / 12,7 \mathrm{a} / 01$.

güzel Güzel, hoş.

g. $6 \mathrm{a} / 02$.

g. ol- İsteğe uygun bir şekil almak, istenildiği gibi olmak. $7 \mathrm{~b} / 03$.

haffāf (<Ar.) Ayakkabı, terlik vb. şeyler yapan ve satan esnaf, kavaf. h. $9 \mathrm{a} / 04$.

hakk (<Ar.) Gerçek. h. $6 \mathrm{a} / 09$.

hakkāk (<Ar.) Maden, taş, tahta vb. üzerine şekiller, özellikle mühür kazan sanatkâr.

h. $10 \mathrm{a} / 08$.

halı Halı.

h. $7 \mathrm{a} / 03$.

halıcı Halı yapan, satan veya döşeyen. h. $9 \mathrm{a} / 06$.

hallā̄c (<Ar.) Pamuk veya yünü bu iş için yapılmış bir âletle, tokmak ve yay ile kabartan kimse, pamuk atıcisı. 
h. $8 \mathrm{~b} / 04$.

ḥammāl (<Ar.) Ücretle yük taşıyan kimse. h. $10 a / 04$.

hāan (<Far.) Serbest meslek sâhiplerine büro veya atölye olarak oda oda veya daire daire kiraya verilen büyük bina. (Kilitciler ḥānı). h. $9 \mathrm{~b} / 05$.

hāar (?) Ar. Hararetli, sıcak. h. $7 \mathrm{~b} / 07$.

hașırcı Hasır yapan, satan veya odalara döşeyen kimse. h. $9 \mathrm{a} / 05$.

ḥelvācı Helva pişirerek dükkânında veya sokakta gezerek satan kimse. h. $9 \mathrm{~b} / 01$.

Hindüstān cevizi Hindistan cevizi. H. $2 \mathrm{a} / 12$.

horașāncı Duvarcı. h. $9 \mathrm{~b} / 11$.

horuz (<Far. ḩurūs) Horoz. h. $1 \mathrm{~b} / 08,4 \mathrm{a} / 04$.

ḩoşāb (<Far.) Hoşaf. h. $1 b / 02,2 b / 10$.

hoşābcı Hoşaf yapıp satan kimse. h. $9 \mathrm{~b} / 08$.

Irḳat (<Yun. ergates) Irgat, amele, rençber. 1. $10 \mathrm{a} / 07$.

i- $\quad$ İmek, cevher fiili. i. $5 \mathrm{a} / 04,7 \mathrm{~b} / 01,7 \mathrm{~b} / 01,7 \mathrm{~b} / 04,8 \mathrm{a} / 01$, 8a/04, 8a/06, 8a/07, 8a/08, 8a/09.

İbrāhim Efendi k.a. Hāzā Kitāb-ı Sarf-ı Türkî́nin yazarı ya da müstensihi. İ. $7 \mathrm{~b} / 09$.

ibrīḳ (<Ar.) Su koymaya yarayan kulplu, emzikli kap.

i. $1 b / 01,2 b / 06$.

iç- İçmek. i. $2 b / 05,2 b / 07,2 b / 09,7 b / 05,7 b / 06$.

igneci İğne yapan veya satan kimse. i. $9 \mathrm{~b} / 03,10 \mathrm{a} / 08$.

imāmeci Kehribar vb.den çubuk imâmesi vb. yapan kimse. i. $9 \mathrm{~b} / 04$.

incīr bk. encīr. i. $2 \mathrm{a} / 03$.

ipci İp üreten, yapan veya satan kimse. i. $9 \mathrm{a} / 10$. ipekci İpek böceği yetiştiren veya ipek böceğinden ipek elde edip satan kimse. i. $9 \mathrm{a} / 06$.

iplikci İplik yapan veya satan kimse. i. $9 a / 10$.

iskemleci İskemle yapan veya satan kimse. i. $10 \mathrm{a} / 03$.

işit- İşitmek. i. $6 \mathrm{a} / 05$.

ķabuḳcı (?) Kabukçu. k. 9a/09.

ḳadāyıfcı Kadayıf yapan veya gezdirip satan kimse.

k. $9 \mathrm{~b} / 01$.

kafesci 1. Pencere kafesi yapan doğramacı.

2. Kafes yapan ve satan kimse. k. $9 \mathrm{a} / 03$.

kaftān $(<$ Far. haftān $)$ Ekserisi süslü ve kyymetli kumaştan, boyu diz kapağına veya topuklara kadar inen, önden açık, bazısının kolları yarıya kadar yırtmaçlı, astarsız hafif üst giyeceği. k. $1 \mathrm{~b} / 04,3 \mathrm{a} / 10$.

kahve (<Ar.) Kahve. k. $1 \mathrm{~b} / 02,2 b / 07$.

kahveci 1. Kahve satan kimse. 2. Herkese açı bir yer (kahvehane) işleten kimse. k. $9 b / 07$.

kāġıt (<Far.) Kâğıt. k. $7 \mathrm{a} / 04$.

kāġıțcı Kâğıt satan, kâğıt tüccarı. 9b/09

kakụule (<Ar. kākulle) Zencefilgillerden, Hindistan, Endonezya, Seylân gibi sıcak iklimlerde yetişen itırlı otsu bitki.

k. $2 \mathrm{a} / 10$.

kalaycı Kalay süren esnaf. k. $9 \mathrm{a} / 07$.

kalem (<Ar.) Kalem. k. 2a/10, 7a/04, 7a/13.

ḳalem-i cengār $(<$ Ar. kalem +Far. jengār $)$ Bakır pası cinsinden bir göz taşı, jengar. k. $2 \mathrm{a} / 10$.

ḳalemtıraş (<Ar. kalem +Far. tirāş) Eskiden 
kamış kalemleri açmakta kullanılan uzun saplı, 15-20 santim boyunda küçük biçak.

k. $7 \mathrm{a} / 04$.

kalıbcı Kalıp yapan, bir şeyi kalıba geçiren veya kalıp satan kimse. k. $10 \mathrm{a} / 06$.

ḳalyoncı Kalyonlarda çalışan deniz eri, denizci. k. $10 \mathrm{a} / 07$.

kanarya (<İsp. canario) Kanarya. k. $1 b / 12,5 a / 01$.

ḳanțarcı 1. Alınıp satılanı tartıp vergiyi toplayan memur. 2. Kantar yapan ve satan kimse. k. $9 \mathrm{a} / 02$.

kaplan Kaplan. k. $1 \mathrm{~b} / 10,4 \mathrm{~b} / 05$.

kaput (<Fr. capote )Yağmurluk, üstlük, milvata.

k. $1 \mathrm{~b} / 04,3 \mathrm{a} / 07$.

karanfil (<Ar.) Karanfil. k. $2 \mathrm{a} / 08,6 \mathrm{~b} / 07$.

kara zirre $(<\mathrm{T} .+$ Far. zìre $)$ Kara kimyon. k. $2 \mathrm{a} / 13$.

ḳardaş ḳanı Asya, Meksika ve Antiller' in tropik bölgelerinde yetişen, çeşitli türleri bulunan, odunundan ince marangozluk ve doğramacilıkta faydalanılan ağaç veya ağaççı şeklindeki bitki.

k. $2 a / 10$.

ḳarulacı (?) Karula yakasını direğe veya yakın münasip bir yere bağlamak üzere tertip edilmiş kamçıları bağlamakla görevli kimse?

k. $10 \mathrm{a} / 10$.

kașșāb (<Ar.) Kasap. k. 8b/08, 9b/10, 10a/04.

ḳașșar (<Ar.) Temizleyici, bez ağartıcı, kasarc1. k. $9 \mathrm{~b} / 06$.

ḳaṣnı (<?)Maydanozgiller familyasından, şeytan tersi, çadır uşağı otu gibi bitkilerden elde edilen bir nevi zamk.

k. $2 a / 13$.

ḳaşık Kaşık. k. $1 \mathrm{~b} / 03,3 \mathrm{a} / 03$.

kasşıķ̣̣ı Şimşir, boynuz, kemik vb.den kaşık yapankimse.

k. $10 / 08$.

katır bk. kațır.

k. 1b/09.

ḳațır Katır. krş. ḳatır.

k. $4 \mathrm{a} / 12$.

kavuḳcı Kavuk yapan ve satan esnaf.

k. $9 \mathrm{a} / 08$.

kavurcı Kahve kavurucusu.

k. $9 \mathrm{a} / 05$.

kayıḳcı Kayık kullanan, kira ile kayığı işleten, bir yalının kayığını kullanan kimse.

k. $8 \mathrm{~b} / 07$.

kaymaḳ Kaymak. k. $2 a / 03,5 b / 01$.

ḳaysı (<Far.) Kayısı. k. $2 \mathrm{a} / 05,5 \mathrm{~b} / 13$.

kaz Kaz.

k. $1 \mathrm{~b} / 08,4 \mathrm{a} / 06$.

ḳazāncı Kazan yapan, tamir eden veya satan kimse. k. 9a/07.

ḳazzāz (<Ar.) İpek satan kimse, gazzaz. k. $9 \mathrm{~b} / 06$.

kebābcı Kebap yapıp satan aşçı. k. $9 \mathrm{~b} / 07$.

kebābiyye (<Ar). Karabibere benzer baharat tanesi.

k. $2 \mathrm{a} / 10$.

kebe $\quad(<$ Yun. kapa < Lat. cappa) Kilim gibi yere serilen, hayvan örtüsü veya çoban kepeneği yapılan çok kalın keçe.

k. $1 \mathrm{~b} / 08,4 \mathrm{a} / 02$.

keçeci Keçe yapan, keçe satan kimse. k. $8 \mathrm{~b} / 04$.

keçi Keçi.

k. 1b/09, 4a/10.

kedi Kedi.

k. $1 \mathrm{~b} / 08,4 \mathrm{a} / 03$.

keklik Keklik.

k. $1 b / 11,4 b / 11$.

kelesteci Keresteci.

k. $9 \mathrm{~b} / 02$.

kerpicci Çiğ tuğla yapan kimse. 
k. $9 b / 02$

keserci Keserci.

k. $9 b / 11$.

kesil- Kesilmek.

k. $7 \mathrm{a} / 13$.

keşkekci Keşkek yapan ve satan kimse.

k. $9 \mathrm{~b} / 08$.

kettāncı Ketenci.

k. $9 \mathrm{a} / 05$.

ḳılabdāncı (<Ar. kullāb+Far dān) Kılaptan yapan veya satan kimse. krş. ḳılābdānc1.

k. $10 \mathrm{a} / 02$.

ḳılābdāncı bk. ḳılabdāncı.

k. 10a/05.

kılıc bk. kılıç.

k. $1 \mathrm{~b} / 03,3 \mathrm{a} / 05$.

kılıccı Kılıç yapan kimse.

k. $9 \mathrm{a} / 01$.

kılıç Kılıç. krş. ḳılıc.

k. $3 \mathrm{a} / 05$.

kııncı Kesici aletler için kılıf yapan kimse. k. $9 \mathrm{a} / 01$.

ḳırmız (<Ar. kirmiz) Kırmız böceğinden çıkan parlak kırmızı renkte boya, çiçek boyası.

k. $2 a / 11$.

ḳıșrag Dişi at.krş. ḳıșraḳ.

k. $1 \mathrm{~b} / 10,4 \mathrm{~b} / 02$.

ḳıșrak bk. kıı̣̂rag.

k. $4 \mathrm{~b} / 02$.

kıymacı Kıyma ustası.

k. 10a/06.

kilim (<Far.) Kilim.

k. $7 \mathrm{a} / 03$.

kilitci Kilit yapan veya satan kimse.

k.+ler ḥānı Kilit Han, Eminönü

Uzunçarşıda yer alan bir han. 9b/05.

kimyūn (< Ar. kemmūn< Yun. kyminon)

Kimyon.

k. 2a/09, 6b/10

kiras (<Yun. kerasi) Kiraz.

k. $2 \mathrm{a} / 04,5 \mathrm{~b} / 10$

kirecci Kireç taşından kireç yapan ve satan kimse.

k. $10 \mathrm{a} / 03$.

kiremitci Kiremit yapan veya satan kimse. k. $9 \mathrm{~b} / 02$.

kirişci Kiriş yapan veya satan kimse. k. 10a/04.

ḳo- Koymak, birakmak. Krş. ḳor-. k.. $2 a / 01,5 a / 08$.

kolancı Hayvanın semerini ya da eyerini bağlamak için kullanılan örme ya da kayış bağı yapan veya satan kimse. k. $9 \mathrm{a} / 09$.

ḳolțuḳcı Koltuk yapan veya satan kimse. k. $9 \mathrm{a} / 08$.

ḳonag bk. knonak. k. $6 a / 11$.

ḳonaḳ Konak. Krş. ḳonag. k. 2a/07.

kopçacı Kopça yapan veya satan kimse. k. 10a/06.

ḳor- bk. ḳo-. k. $2 \mathrm{a} / 01$.

kork- Korkmak. k. $8 \mathrm{a} / 02$.

koyun Koyun. k. $1 \mathrm{~b} / 09,4 a / 08$.

kömürci Kömür ticareti yapan kimse. k. $8 \mathrm{~b} / 07$.

köpek Köpek. k. 1b/11, 4b/07.

köşk $\quad(<$ Far. kuşk) Köşk, kasır. k. 2a/07, 6b/01.

kubūrcı Kuburcu, mezarcı. k. $10 \mathrm{a} / 12$.

kumbaracı Kumbara atan er, humbaracı. k. $10 \mathrm{a} / 05$.

ḳumrı (<Far. kumrī) Kumru. k. $1 \mathrm{~b} / 12$.

kulaḳ Kulak. k. $2 \mathrm{a} / 06,6 \mathrm{a} / 05$.

kundaḳçı Tüfek kundağı yapan usta. k. $9 \mathrm{a} / 02$.

kurd bk. kurt. k. $1 b / 11,4 b / 08$

kurt Kurt. krş. kururd. k. $4 \mathrm{~b} / 08$.

ḳuru yemişci Kuru yemiş satan kimse veya kuru yemiş satılan yer. k. $8 \mathrm{~b} / 05$.

kuş̧ạ̦ Kuşak. k. $7 a / 04,7 a / 11$.

kuş̧aḳcı Kuşak yapan veya satan kimse. k. 9a/09. 
kuțucı Kutu yapan veya satan kimse. 9a/03, k. $10 \mathrm{a} / 04$.

kuzı bk. kuzu. k. $4 \mathrm{a} / 09$.

ḳuzu Kuzu. krş. ḳuzı. k. 1b/09, 4a/09.

kükürt (<Far. gūgird) Kükürt. k. 2a/11.

küpci Küp yapan veya satan kimse. k. $10 \mathrm{a} / 11$.

kürk Kürk. k. 1b/04, 3a/09.

kürkci Kürk yapan ve üstlük giyeceklere kürk kaplayan kişi.

k. $10 \mathrm{a} / 02$.

laġımcı 1. Lağım temizlemekle görevli işçi. 2.Düşman kale ve siperlerini atmak için lağım kazan asker ve bu işle görevli sınıf.

1. $10 \mathrm{a} / 07$.

lāle $\quad(<$ Far.) Lale.

1. $2 \mathrm{a} / 08,6 \mathrm{~b} / 06$.

leblebici Leblebi yapan veya satan kimse.

1. $8 \mathrm{~b} / 04$.

limoncı Limon satan kimse.

1. $8 \mathrm{~b} / 08$.

loțūr (<Yun.) Aromatik bir bitki (symplocos racemosa).

1. $2 \mathrm{a} / 11$.

lüleci Çamurdan çubuk lülesi ve ona benzer şeyler yapan kimse.

1. $9 \mathrm{~b} / 06$.

maḥbūb (<Ar.) Sevgili. m. $6 \mathrm{a} / 06$.

maḳascı Makas yapan veya satan kimse. m. 9a/09.

manda Manda. m. 1b/09, 4a/11.

māşa (<Far.) Maşa. m. 1b/02.

māżı $(<$ Far. $m \bar{a} z \bar{u}) \quad$ Servigillerden, yaprakları almaşık ve küçük pullar biçiminde, gövdesi düz olan, dipten dallanan bir süs bitkisi.

m. 2a/11.

mest (<Ar.) Üzerine mesh edilebilen, kısa konçlu, hafif ve yumuşak bir ayakkabı türü. m. $1 b / 06,3 b / 03$.

meyḥāneci Meyhâne işleten kimse, şarapçı. m. 10a/11

mezarcı Mezar kazan, mezarların bakımını yapan kimse. m. 10a/12.

miḳrāṣ (<Ar. miḳāạs/mikrāż) Kesecek âlet, makas.

m. $1 b / 01,2 b / 02$.

minder İçi yumuşak bir malzeme ile doldurularak dikilen, oturmaya, yaslanmaya yarar şilte. m. 7a/03, 7a/05.

misvākcı Misvak yapan veya satan kimse. m. 10a/08.

muhallebci Muhallebici. m. 10a/09.

mūm (<Far.) Mum. m. $1 \mathrm{~b} / 01,2 \mathrm{~b} / 03$.

mūmcı 1. Mum yapan veya satan kimse. 2 . Eskiden fitilli tüfek ile silahlanmış asker. m. 10a/10.

mūțaf $(<$ Far. $m \bar{u} y$-tāb) Dokumak veya örmek suretiyle keçi kılından çul, yem torbası vb. şeyler yapan ve satan kimse, muytaf.

m. 10a/02.

mücellid (<Ar. mucellid) Cilt yapan kimse, ciltçi. m. 10a/02.

mühreci Duvarcı ustası. m. 10a/03.

mürekkebci Yazı yazmakta kullanılan boya ve bilhassa bezir işinden mürekkebi yapan ve satan kimse. m. 9b/09.

naḳkāşs (<Ar.) Renkli resim ve tezyinat yapan sanatkâr, kitapları resimleyen, kap ve sayfalarını süsleyen, mimarî eserlerin tavan ve duvarlarını, çinileri, toprak kapları vb.lerini resim ve şekillerle bezeyen süsleme ustası.

n. $9 \mathrm{~b} / 02$.

nalbant (Ar. $n a^{\prime} l+$ Far. bend) At vb. hayvanları nallayan kimse. n. $8 \mathrm{~b} / 03$. 
nalbur (Ar. na'l +Far. ber) Saç ve demirden nal, çivi, maşa vb. eşya yapan kimse. n. $9 \mathrm{a} / 04$.

nalçacı Nalcı.

$$
\text { n. 9a/02. }
$$

nār (<Far.) Nar.

$$
\text { n. 2a/04, 5b/09. }
$$

nışādır (<Ar. nevşādur) Amonyak tuzu, amonyum klorür.

$$
\text { n. } 2 \mathrm{a} / 11 \text {. }
$$

oduncı Ormandan odun kesip taşıyan veya başkalarının kesip taşıdıkları odunları yığıp satan kimse.
o. $10 \mathrm{a} / 12$.

oḳu - Okumak.

$$
\text { o. } 8 \mathrm{a} / 10 \text {. }
$$

ol- olmak.

$$
\text { o. } 7 \mathrm{~b} / 03,7 \mathrm{~b} / 08 \text {. }
$$

oturaḳcı İskemleci, sandalyeci.

$$
\text { o. } 9 \mathrm{a} / 08 \text {. }
$$

öküz Öküz.

$$
\text { ö. 1b/10, 4b/01. }
$$

ördek Ördek.

ö. 1b/08, 4a/07.

örekeci Öreke (yün ipliği yapmak için kullanilan alet) yapan veya satan kimse.

$$
\text { ö. } 9 \mathrm{~b} / 04 \text {. }
$$

örekci (?) bk. örekeci.

$$
\text { ö. } 9 b / 09 \text {. }
$$

örücü 1. Kumaşlardaki yırtıkları, delikleri örerek tâmir eden. 2. Duvar yapan veya onaran kimse, yapı ustası.
ö. $10 \mathrm{a} / 01$.

pabuc bk. papuc.

$$
\text { p. 1b/06. }
$$

pabuccı Ayakkabı yapan veya satan kimse, ayakkabıcı.

p. $8 \mathrm{~b} / 02$.

pambuḳcı Pamuk alıp satan kimse. p. 9a/07.

panayır (<Yun. paneyiri) Belli zamanlarda belirli yerlerdeki meydanlarda kurulan büyük pazar.

p. 1b/03, 3a/01.

pambuḳcı Pamuk satan tüccar.

$$
\text { p. } 9 \mathrm{a} / 07 \text {. }
$$

papuc (<Far. $p \bar{a}-p \bar{u} s ̧)$ Pabuç. krş. pabuç. p. $3 b / 04$. parmaḳcı Çıkrıkçı esnafından parmaklık ve tırabzan parmağı yapan kimse. p. 9b/04.

pașdırmacı Pastırma yapan veya satan kimse. p. 9a/08.

pekmezci Pekmez yapan veya satan kimse. 9b/08, 10a/06

peşkir (<Far. piş̧-gīr) Pamuk ipliğinden dokunmuş havlu. p. $1 b / 07,3 b / 11$.

peygamber àgacı $(<$ Ar. $+\mathrm{T})$ Yabani kimyongillerden, Antil Adalari'nda ve Venezuela'da yetişen, 10-15 metre yüksekliğinde, kışın yapraklarını dökmeyen, reçinesinden gayakol çıkarılan bir ağaç. p. $2 a / 13$.

pirincci Pirinç satan kimse. p. $8 b / 07$.

rāhst (<Far. raht) At takımı; yol gereçleri. r. 1b/06, 3b/07.

rastık (<Far). Antimon tozundan yapılan, hanımların kaşlarını veya saçlarını boyamak için kullandıkları siyah boya.

r. $2 \mathrm{a} / 11$.

sā'atci Saat yapan, satan veya tamir eden kimse. s. $9 a / 04$.

șābūncı Sabun yapan veya satan kimse. s.. $8 b / 08,9 b / 05$.

șaçıḳıbrız (<?)Demir sülfat. s. $2 \mathrm{a} / 13$.

șafrancı Safran alıp satan kimse. s. 9b/05.

samancı Saman alıp satan kimse. s. $10 \mathrm{a} / 12$.

șandıḳcı Sandık yapan veya satan kimse. s. 9b/05.

șaḥhāf (<Ar.) Yazma ve basma eserler alıp satan kitapçı.

s. $10 \mathrm{a} / 01$.

șarāc (<Ar. serrāc) At takımları, eyer ve koşum yapan veya satan kimse. s.. 8b/03, 10a/06.

șarık Fes, külâh, kavuk gibi başa giyilen 
şeyler üzerine sarılan tülbent, şal vb., imame, destar.

s. $7 \mathrm{a} / 04,7 \mathrm{a} / 12$.

sebzevātcı Sebzeci, zerzevatçı.

s. $9 \mathrm{~b} / 11$.

seccāde (<Ar.) Namazlık.

s. $7 \mathrm{a} / 03,7 \mathrm{a} / 09$.

senā Ar. İhtişam. (Steingass, 1998, s. 699) s. $7 \mathrm{~b} / 06$.

sepetci Sepet yapan veya satan kimse.

$$
\text { s. } 10 \mathrm{a} / 05 \text {. }
$$

serçe Serçe.

$$
\text { s. } 1 b / 12,4 b / 13 \text {. }
$$

sev- Sevmek.

s. $8 \mathrm{a} / 01,8 \mathrm{a} / 02,8 \mathrm{a} / 03,8 \mathrm{a} / 04$, $8 \mathrm{a} / 05,8 \mathrm{a} / 06,8 \mathrm{a} / 07,8 \mathrm{a} / 08,8 \mathrm{a} / 09$.

seveddehü (<Ar.) Metinde "yazdl, karaladı" anlamında kullanılmıştır. s. $7 \mathrm{~b} / 09$.

șırıḳcı Sırıklara taktıkları fıçıları taşıyan hamal.

s. $10 \mathrm{a} / 09$.

simitci 1 . Simit yapan ekmekçi. 2. Simit gezdirip satan kimse. s. $9 b / 10$.

sināmekī (<Ar.) Baklagillerden, sıcak bölgelerde yetişen, yaprağı müshil olarak kullanılan, sarı çiçekli, otsu veya ağaçsı bitki.

s. $2 a / 09$.

sirkeci Sirke yapan veya satan kimse.

$$
\text { s. } 10 \mathrm{a} / 01 \text {. }
$$

șofra (<Ar. sufre) Sofra.

s. $1 \mathrm{~b} / 03,3 \mathrm{a} / 02$.

șor- Sormak.

s. $2 a / 02,5 a / 11$

süd Süt.

$$
\text { s. } 2 \mathrm{a} / 03
$$

șu Su.

s. $2 b / 09$

sünbül (<Far. sunbul) Sümbül.

s. 2a/08, 6b/05.

şāhin (<Far.) Şahin.

ş. $1 b / 12,5 a / 03$.

şam 'dān (<Ar. şem'+Far. dān) Şamdan.

s. $1 b / 01,2 b / 01$.

şāl $\quad$ (<Far.) Şal.

ş. 7a/04, 7a/10. şālcı Şal satan kimse.

ş. 10a/09.

şeftāli $(<$ Far. şeftālū $)$ Şeftali.

ş. 2a/05, 6a/01.

şeker (<Far.) Şeker.

s. $1 b / 02,2 b / 11$.

şekerci 1 . Şeker yapan ve satan kimse. 2.Şekerleme, reçel, şurup çeşitlerini yapip satan kimse.

ş. $8 \mathrm{~b} / 04$.

şerbet (<Ar.) Şerbet. ş. $1 \mathrm{~b} / 02$.

şerbetçi Şerbet, limonata gibi şeyler yapan veya satan kimse.

ş. $9 b / 07$.

şīşeci Şişe satan kimse. ş. 9b/03.

ța'ām (<Ar.) Yemek, aş. t. $2 \mathrm{~b} / 08,7 \mathrm{~b} / 04$.

tacir (<Ar.) Ticaretle uğraşan kimse, tüccar.

t. $10 \mathrm{a} / 01$.

tahmīsci Kuru kahveci.

$$
\text { t. } 9 \mathrm{a} / 05 \text {. }
$$

țaraḳcı Tarak yapan ve satan kimse.

t. $9 b / 06$.

țaşcı 1. Yapı vb. için ocaktan taş çıkarıp satan kimse. 2. Mermer vb. gibi taşları yontarak çeşitli şeyler yapan kimse.

t. $8 \mathrm{~b} / 06$.

țavşan Tavşan.

ț. $1 b / 11,4 b / 10$.

tavuk Tavuk.krş. țavuk. t. $1 \mathrm{~b} / 08,4 \mathrm{a} / 05$.

țavuk bk. tavuk. t. $4 a / 05$.

țavuḳcı 1. Tavuk satan kimse. 2. Tavuk yetiştiren.

t. $9 \mathrm{~b} / 10$

tekneci Tekneci. t. $8 \mathrm{~b} / 06$.

tekyeci Tekkeyi idare eden.

t. $10 \mathrm{a} / 05$.

tellāk (<Ar. dellāk) Çarşı hamamında erkekleri yıkayan, keseleyen kimse, dellak.

t. $10 \mathrm{a} / 04$. 
temürci 1. Demir işleyip çeşitli aletler yapan zanâatkâr. 2. Demir satan, demir ticareti yapan kimse.

t. $9 \mathrm{a} / 01$.

tenekeci Tenekeden çeşitli kaplar yapan ve teneke onaran kimse.

t. $9 \mathrm{~b} / 03$.

terlikçi Terlik yapan veya satan kimse.

$$
\text { t. } 9 \mathrm{~b} / 07 \text {. }
$$

terzi $\quad(<$ Far. derzīi $)$ Terzi.

$$
\text { t. } 8 \mathrm{~b} / 02 \text {. }
$$

tesbiḥci Tespih yapan veya satan kimse.

t. $10 \mathrm{a} / 08$.

tilki Tilki.

$$
\text { t. } 1 b / 11,4 b / 06 \text {. }
$$

topcı Topların kullanılması, bakımı ve taşınması ile uğraşan asker sınıfı. t. 10a/05.

ton Elbise.

t. $1 \mathrm{~b} / 05,3 \mathrm{~b} / 01$.

tökmeci Dökmeci, erimiş madenleri kalıba dökmek suretiyle çeşitli eşyalar yapan kimse, dökücü, dökümcü.

$$
\text { t. 10a/07. }
$$

țūṭī (<Far.) Papağan. krş. țūtī, țūṭu.

$$
\text { ț. 1b/12, 5a/02. }
$$

tūùī bk. țūțī.

$$
\text { ț. } 5 \mathrm{a} / 02 \text {. }
$$

țurşucu Turşu kurup satan kimse.

$$
\text { t. } 10 \mathrm{a} / 01 \text {. }
$$

țūțu bk. țūṭī.

$$
\text { ț. } 5 \mathrm{a} / 02 \text {. }
$$

tuz Tuz.

$$
\text { t. } 1 b / 02,2 b / 12 \text {. }
$$

tuzcı Tuz satan kimse.

$$
\text { t. } 8 \mathrm{~b} / 06 \text {. }
$$

tüfenk (<Far. tufeng) Tüfek, Uzun namlulu, taşınabilir ateşli silah.

t. 1b/04, 3a/06.

tülbentci Tülbent yapan veya satan kimse. t. $9 \mathrm{~b} / 04$.

tütün Tütün.

$$
\text { t. } 2 b / 05 \text {. }
$$

tütün ḳıyıcı Ham tütünü kıyıp satan

$$
\text { kimse. }
$$

t. $10 \mathrm{a} / 06$

'ūdü'l-ḳahrr (<Ar. Pisik otu. Keskin kokulu, mor çiçekli bir bitki. 'ū. 2a/10.

unḳapancı Un tartan kimse.

u. $10 \mathrm{a} / 10$.

usturacı Ustura yapan veya satan

kimse.

u. $10 \mathrm{a} / 08$.

üzüm Üzüm.

$$
\text { ü. 2a/04, 5b/05. }
$$

vezneci Terazi vb. yapan usta.

$$
\text { v. } 10 a / 10 \text {. }
$$

vir- Vermek.

$$
\text { v. 2a/01, 5a/07. }
$$

yag̀ Yağ. y. $2 \mathrm{a} / 03,5 \mathrm{~b} / 02$.

yaġcı Sade yağ yapan ve satan kimse. y. $9 \mathrm{a} / 08$.

yag̉lık Sırma işlemeli, büyük mendil, çevre. y. $1 b / 07,3 b / 10$

yağlıḳcı Çevre, havlu, iç çamaşırı, yağlık vb. satan kimse. y. 10a/05.

yan- Yanmak. y. $2 b / 03$.

yașdık Yastık. y. 7a/03, 7a/06.

yașdıḳcı Yastıkçı, yastık yapan veya satan kimse. y. 10a/02.

ye- Yemek. y. 2b/08, 2b/13, 4a/06, 4a/08, 4a/09, $6 \mathrm{a} / 01,7 \mathrm{~b} / 04,7 \mathrm{~b} / 05,7 \mathrm{~b} / 06$.

yelek Yelek. y. $1 b / 05,3 a / 12$.

yemān̄ī $(<$ Ar. yemenī) Yemeni, Kalıpla basılip elle boyanan, kadınların başlarına bağladıkları tülbent. y. $1 b / 07,3 b / 09$.

yemenici Yemeni yapan ve satan kimse. y. $8 \mathrm{~b} / 03$.

yenibahār Mersingillerden, Amerika'nın sicak bölgelerinde yetişen bir bitki. y. 2a/08, 6b/09.

yine Gene, tekrar. y. 10a/04.

yoġurtcı Yoğurt yapan veya satan kimse.

$$
\text { y. } 9 b / 01 \text {. }
$$

yorgan Yorgan.

$$
\text { y. } 7 \mathrm{a} / 03,7 \mathrm{a} / 07 \text {. }
$$

yorgancı 1. Yatak yorganı yapan ve satan 
kimse. 2. Oda döşemek ve yaygıları hazırlayıp yerli yerine takmak sanatını bilen ve yapan esnaf. y. $9 \mathrm{a} / 06$.

yumurțacı Yumurta satan kimse. y. $8 \mathrm{~b} / 05$.

yüzerlik Üzerlik, sedef otugillerden, ac1 tohumları susama benzeyen, beyaz çiçekli, çok dallı, halk arasında tütsü olarak kullanılan sicak bölge bitkisi. y. $7 \mathrm{a} / 02$.

yüzlük (?) Üzerlik otu. y. 2a/13.

za ferān (<Ar.) Safran.

\section{SONUÇ}

Elimizdeki veriler, Türkçenin yapısı ile ilgili olarak 16-19. yüzyıllar arasında yazılmış günümüze ulaşan tek eserin Bergamalı Kadri'nin Müyessiretü'l-ûlum (M. 1530)'u olduğunu göstermekteydi. Bu çalı̧̧ma, Osmanlı sahasında Hāzāa Kitāb-1 Sarf-1 Türkî (M. 1786)'nin, Müyessiretü'l-ûlum'dan sonra günümüze ulaşan ikinci gramer kitabı olduğunu ortaya koymaktadır. Eser, ses uyumları açısından bir geçiş devresi sayılan 18. yüzyıl yani Orta Osmanlıca denilen devredeki ses uyumlarını içermesi bakımından da değerlidir. Sarf aynı zamanda dilin doğru okunup yazılmasıyla ilgili kuralları bildirmek için de yazıldığından yazar bazı sözcükleri harekeli ve okutucu ünlülerle yazmıştır. Yazar eklerin yazımında kalıplaşmış imlaya uyduğu gibi zaman zaman da söyleyişi esas almıştır.

Hāzāa Kitāb-1 Sarf-1 Türkî, 18. yüzyıl Türkçesinin şekil özelliklerinin yanı sıra dönemin sosyal hayatıyla ilgili bilgiler de vermektedir. Yazar eserine isimlerin yalın hâllerini vererek başlamış, sonrasında bu isimlerin iyelik çekimlerini vermiştir. Bu 149 isimden Türkçe kökenliler 69 (\% 46), Farsça kökenliler 36 (24), Arapça kökenliler 24 (\%6), Yunanca, İspanyolca, Fransızca vb. kökenli kelimeler 8 (\%5), Arapça+Farsça kökenli 6, Farsça+Arapça kökenli 2, Arapça+Türkçe kökenli 1, Türkçe.+Arapça kökenli 1 (\%6.8), kökeni bilinmeyenler 2 (\%1)'dir. Seçilen bu isimler ve eserin sonundaki meslek isimleri dönemin aile ve çalışma hayatına, yemek kültürüne yani 18. yüzyılın günlük hayat sosyolojisine dair bilgiler vermektedir. Eser varak sayısına oranla (1b-10a) zengin bir söz varlığına sahiptir. İsimlerin yanı sıra günlük hayatta sıklıkla kullanılan fiillerin basit ve birleşik zamanlı çekimleri verilmiştir. Yazarın belirgin bir metodu yoktur. Eserde iyelik çekimleri ve fiil çekimleri düzensiz bir şekilde verilmiştir. Eser, Türkçenin şekil bilgisini bütünlüklü veren bir çalışma değildir ancak yazarın metinde sıraladığı sözcük ve eklerle dönemin konuşma dilinin yansıtmayı amaçladığı anlaşılmaktadır.

\section{Extended Abstract}

In Ottoman Turkish, the terms sarf and nahw were used for grammar: sarf was used for studies on structure, syntax; and the term nahw was used for studies on sentence knowledge, morphology. In sarf books, the goal is to ensure that the language is read, written and spoken correctly and to set out its rules. Historical Turkish Grammar studies began with the lost work of Mahmud al-Kashgari in the second half of the 11th century: Kitâbu Cevâhiri'n Nahv fi-Lûgat-itTürk. After these periods, grammatical studies related to Turkey Turkish have been discussed in three titles: grammars of the Ottoman period, grammars of the Tanzimat period and grammars of the Republican period. The most unfruitful of these periods is the Ottoman period. There are 
no grammatical studies dating back to this period apart from the lost grammar work of Divriğili Fahreddin Efendi entitled Kasîdetü fi-Kavâid-i Lisâni't-Türk, which he wrote in the 13th-14th centuries; and the work of Muyessiretü'l-Ulûm (1530) by Kadrî of Pergamon.

Hāza $\bar{a}$ Kitāb-ı Sarf-ı Türkî, a book on morphology written in the 18th century, is the second extant grammar book written in the Ottoman field, regarding the structure of the Turkish language between 16th-19th centuries after Muyessiretü'l-Ulûm by Kadrî of Pergamon. The work is in the collection of Oriental Manuscripts in the Berlin State Library (Staatsbibliothek zu Berlin Preußisscher Kulturbesitz/Orientalische Handschriften). It is a small morphology book registered with the number Ms. Diez A quart. 95, between 1B-10a leaves. In the colophon section on 7b, the date H. 1201 (C.E. 1786) and the phrase "seveddehü Ibrahim Efendi" are found. It was Heinrich Friedrich von Diez (1751-1817) who found the manuscript and donated it to the library. Hāza $\bar{a}$ Kitāb-ı Sarf-ı Türkî has been open to access in the Berlin State Library since 6 September 2019. The number of lines between 1b-7a leaves of the work is thirteen, yet on the next leaves is irregular. The type of writing is Diwani. It was written with black ink. It is a brown leather-bound book. The page size is $21.5 \times 15.5 \mathrm{~cm}$, and the book size is $21.9 \times 15.7 \times 0.4 \mathrm{~cm}$. Between the $1 \mathrm{~b}-7 \mathrm{~b}$ pages of the work, the names of goods-tools, horse riding-harnesses, beverages, weapons, clothes, shoes, fabric, animals, food, fruits, organs, dwellings, plants-spices, paints and chemical substances are listed. Possessive suffixes of many of these names are provided, but there are irregularities in them and some of the words are left without suffixes. On the 2a/01-03, simple verb inflections; and between $5 \mathrm{a} / 04-13$ and $7 \mathrm{~b}-8 \mathrm{a}$ leaves, simple and compound tense verb inflections are given. Between the 8b-10a leaves of the work, 193 occupational titles of 18thcentury Istanbul are listed under the subheading "Bâb u fî Beyân-1 Esnâfları". It is noteworthy that there are place names here besides occupation names. The work is noteworthy as it is the oldest grammar book after Müyessiretü'l-Ulûm and as it includes the lexical and morphological features of 18th-century Turkish. Also, it is significant for it sheds light on the social and professional life of 18th-century Istanbul and the daily life culture of the period.

The study consists of three parts, except the introduction and conclusion. In the first part, the work was examined; in the second part, the text was transcribed; and in the third part, the dictionary section was included. The aim of this article is to introduce the work to the world of Turkology and to contribute to the studies on 18th-century Turkish. 


\section{KAYNAKÇA}

Ahmed Vefik Paşa (1306/1890). Lehçe-i Osmânî. İstanbul: Mahmûd Bey Matbaası.

Ayverdi, İ. \& Topaloğlu, A. (2005). Misalli büyük Türkçe sözlük. İstanbul: Kubbealtı Neşriyatı.

Baykal, B. S. (1974). Tarih terimleri sözlüğü. Ankara: Türk Dil Kurumu Yay.

Bilge, S. M. (2018). Osmanl İstanbul'unda esnaf ve ticaret. İstanbul: Kitabevi.

Carbognano, C. C. (1993). 18. yüzyllın sonunda İstanbul. (E. Özbayoğlu, Çev.). İstanbul: Eren Yay.

Çetin, N. M. (1971). Yazma eserlerin tanınması. Ilim ve Sanat, 59, 59-64.

Deny, J. (1941). Türk dili grameri (Osmanlı lehçesi) (A. U. Elöve, Çev.). İstanbul: Maarif Vekaleti Yay.

Develi, H. (1998). XVIII. Yüzyıl Türkiye Türkçesi üzerine. Doğu Akdeniz Türk Dili ve Edebiyatı Dergisi,
1 ,
27-36.
Erişim
adresi:
https://www.academia.edu/30694708

/18_Y\%С3\%BCzy\%C4\%B11_T\%C3\%BCrkiyeT\%C3\%BCrk\%C3\%A7esi_\%C3\%9Czerine

Duman, M. (1998). Damak ünsüzlerinin klasik Osmanlı Türkçesi dönemindeki gelişmelerine

dair. Doğu Akdeniz, 1, 1-26.

Erdal, M. (1994). Vowel harmony in the hebrew script version of the anonymous Tevârîh-i Âl-i

'Oșmân. A. Borg\&M. Erdal (Ed.), Mediterranean language review (8) içinde (s. 68-76).

Harrassowitz Verlag Wiesbaden. https://www.academia.edu/12830112/VOWEL_HARMONY_IN_THE_HEBREW_SCRIPT_VER SION_OF_THE_ANONYMOUS_TEVARIH-I_AL-I_OSMAN

Kahraman S. A. \& Dağlı Y. (Haz.). (2003). Günümüz Türkçesiyle Evliya Çelebi seyahatnamesi: İstanbul. (C. 1). İstanbul: Yapı Kredi Yay.

Karabacak, E. (1999). Başlangıçtan Cumhuriyet'e kadar gramer kitaplarımız. H. Y. Nuhoğlu (Der.), Osmanh Dünyasında Bilim ve Eğitim Milletlerarası Kongresi Tebliğleri içinde (s. 629-635), İstanbul: IRCICA Yay.

Karabacak, E. (2018). A linguistic evaluation of the preface of "Mikyasu'l-Lisan Kistasu'l-Beyan"

by Abdurrahman Fevzi Efendi. SHS Web of Conferences, 48, 01036, 1-12. Erişim adresi: https://doi.org/10.1051/shsconf/20184801036.

Kartallığlu, Y. (2011). Klasik Osmanl Türkçesinde eklerin ses düzeni (16, 17 ve 18. yüzyıllar). Ankara: Türk Dil Kurumu Yay.

Koç, M. (2007). Bilim tarihinin ilk yapma dili Bâleybelen. Z.Dilek \& M.Akbulut \& E.Kâhya \& Z. Bağlan Özer \& R.Gürses \& B. Karababa Taşkın (Haz.), 38. ICANAS Uluslararası Asya ve Kuzey Afrika Çalışmaları Kongresi Bildirileri içinde (s. 269-278), Ankara: Atatürk Kültür, Dil ve Tarih Yüksek Kurumu Yay.

Koçu, R. E. (2016). Tarihte İstanbul esnafi. İstanbul: Doğan Kitap.

Korkmaz, Z. (1992). Gramer terimleri sözlüğü. Ankara: Türk Dil Kurumu Yay.

Korkmaz, Z. (2002). Türkiye Türkçesindeki gramer çalışmaları ve çalışmaların günümüzdeki durumu. Türk Dili Araştırmalar Yilliğı Belleten, 50(1), 41-59. Erişim adresi: http://tdk.gov.tr/dosyalar/TDA/2002_1/2002_1_05_Korkmaz.pdf.

Korkmaz, Z. (2019). Türkiye Türkçesi Grameri (Şekil Bilgisi). Ankara: Türk Dil Kurumu Yay.

Koyuncu, M. (2004). 18. yüzyllın ikinci yarısında Osmanlı esnafı (İstanbul ve Bursa örnekleri) (Doktora tezi, Gazi Üniversitesi, Ankara ). Erişim adresi: https://tez.yok.gov.tr/UlusalTezMerkezi/tezSorguSonucYeni.jsp

Meninski, F. (1680). Thesaurus linguarum orientalium-lexicon Turcico-Arabico-Persicum. Avusturya.

Pakalın, M. Z. (1983). Osmanlı tarih deyimleri ve terimleri sözlüğü (C. 3). İstanbul: MEB Yayınevi.

Redhouse, J. W. (1987). A Turkish and English lexicon. New Impression. Beyrut, Librairie du Liban.

Steingass, F. J. (1998). A comprehensive Persian-English dictionary. Lübnan.

Şemseddin Sami (1317/1901). Kāmûs-ı Türkî. İstanbul: İkdâm Matbaası.

Toprak, Z. (2004). Zanaattan küçük ve orta büyüklükteki işletmelere lonca'dan kobi'ye -esnaf ve sanatkârnn dünü. İstanbul: Osmanlı Bankası Müzesi.

Timurtaş, F. K. (1997). Osmanlı Türkçesine giriş̧ (C.I-III). İstanbul Üniversitesi Edebiyat Fakültesi Yay.

\section{Elektronik kaynaklar:}

Hāzā Kitāb-ı Sarf-ı Türkî. (M.1786). https://digital.staatsbibliothek-berlin.de/werkansicht?PPN= PPN1049145127\&PHYSID=PHYS_0004\&DMDID= Erişim tarihi: 06.10.2019 
İSAM Tahkikli Neşir Esasları (İTNES). http://www.isam.org.tr). Erişim tarihi: 01.02.2020.

Schmiede, H. A. (t.y.) Dede Korkut araştırmacılığının banisi: Türk medeniyetinin bilgin âşığı Heinrich Friedrich von Diez (1751-1817) 250 yıl önce doğdu. https://core.ac.uk/download/pdf/161801578.pdf. Erişim tarihi: 10.02.2020.

TDK, Türkçe Sözlük, https://sozluk.gov.tr/ Erişim tarihi: 20.01.2020.

TDK, Derleme Sözlüğü, https://sozluk.gov.tr/ Erişim tarihi: 02.02.2020.

TDK, Tarama Sözlüğü, https://sozluk.gov.tr/ Erişim tarihi: 02.02.2020. 